\title{
Melanoma vaccines: trials and tribulations
}

This article was published in the following Dove Press journal:

Vaccine: Development and Therapy

9 October 2013

Number of times this article has been viewed

\section{Robert O Dillman ${ }^{1,2}$}

'Hoag Cancer Institute and Hoag Institute for Research and Education, Newport Beach, CA, USA; ${ }^{2}$ University of California Irvine, Irvine, CA, USA

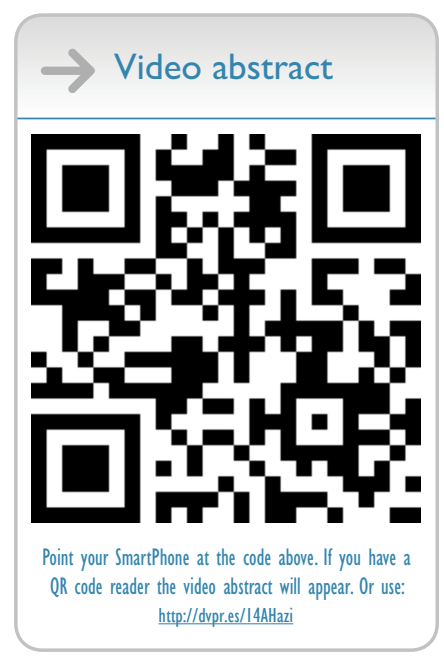

Correspondence: Robert O Dillman Hoag Institute for Research and Education, 3900 Pacific Coast Highway, Suite 210A, Newport Beach, CA 92663, USA

Email robert.dillman@hoag.org
Abstract: Metastatic melanoma has been a target of immunotherapy for more than 4 decades. Three immunotherapeutics have received regulatory approval for treating melanoma: interferonalpha, interleukin-2, and ipilimumab. The antitumor mechanisms of these products depend on enhancing existing immune responses, including autoimmune effects. The combination of autologous, cytotoxic T-lymphocytes plus high-dose interleukin-2 is a promising patient-specific therapy, but has limited clinical application. Other approaches include vaccines targeting melanoma-associated antigens, and patient-specific vaccines that utilize autologous tumor. Nonpatient-specific vaccine approaches target melanocyte differentiation antigens (eg, tyrosinase, Melan-A, gp100), antigens identified by cytotoxic T-lymphocytes (eg, NY-Eso-1, Melan-A/Mart1, Mage-3), and antigens originally identified by murine monoclonal antibodies (gangliosides, gp97, gp225). Self-renewing cells in tumor cell lines may represent tumor stem cells, but vaccines derived from allogeneic tumor cell lines have yielded disappointing results in randomized trials. Patient-specific vaccines can be derived from bulk autologous tumor or autologous tumor cell lines, and intratumoral injections of immunostimulatory fusion products have shown promise. While technically more complex to manufacture, patient-specific vaccines derived from autologous tumor cell lines have the potential to target tumor stem cells and overcome interpatient tumor cell heterogeneity. This article reviews sources of melanoma-associated antigens, costimulatory agents, and clinical trial results for various melanoma vaccines. Comparing Phase II trials is difficult because of the wide range of vaccine strategies and the differences in study patient populations; therefore, randomized trials are necessary to prove the efficacy of such products. Therapeutic vaccines are more likely to enhance, rather than replace, other antimelanoma immune therapies. In particular, effective vaccines may be synergistic with products that block T-cell immune checkpoint molecules such as ipilimumab and monoclonal antibodies that interfere with programmed death ligand-receptor interactions.

Keywords: melanoma, vaccines, melanoma-associated antigens, melanoma stem cells, dendritic cells, GM-CSF, checkpoint molecules

\section{Immunotherapy of melanoma}

The adaptive immune system is an iterative process involving processing and presentation of antigen particles to T-lymphocytes by dendritic cells (DC) in the context of human lymphocyte antigens (HLA), also known as histocompatibility antigens. This interaction is regulated by membrane receptors, coexpression molecules, and checkpoint molecules that limit autoimmunity. ${ }^{1,2}$ Once induced, T-lymphocytes provide cellular immunity and B-lymphocytes humoral immunity, with the participation of helper and suppressor T-cells, memory T-cells, cytotoxic T-cells, natural killer cells, regulatory 
T-cells that help limit autoimmunity, and a process of B-cell differentiation that results in continuous improvement in the affinity and avidity of antibodies to antigen. Cancer immunology is a complex balance between immune recognition of self and non-self, and adaptive processes by cancer cells that help them evade immune recognition. ${ }^{3}$ The iterative process of immunoediting results in continuous improvement in specific immune recognition of foreign molecules that affect cancer suppression and promotion. ${ }^{4}$ Especially challenging is that cancer cells in each patient contain the same basic genetic material as all other cells in that individual. Consequently, cell mechanisms that protect against autoimmunity can also limit immune recognition of autologous cancer cells. Cancer immunotherapy involves stimulation, augmentation, or suppression of various aspects of the immune system. Cancer immunotherapeutics include foreign agents that enhance inflammatory responses, monoclonal antibodies that target tumor-associated antigens, immune signaling cytokines that have broad nonspecific immune-stimulating effects, agents designed to block specific cell interactions that inhibit autoimmunity, and immune cells. ${ }^{5}$

Anti-melanoma effects mediated by the host immune system have been recognized for many years and include rare cases of spontaneous regression of distant metastases ${ }^{6,7}$ and the favorable prognostic implications of tumor-infiltrating lymphocytes in both primary tumors ${ }^{8}$ and lymph node metastases. ${ }^{9}$ Melanoma has been a focus of anticancer immunotherapy for more than 4 decades. The nonspecific immune stimulating agent bacille Calmette-Guérin (BCG) was tested extensively during the 1970s before it was concluded to be of limited therapeutic benefit for preventing melanoma recurrence or treating metastatic melanoma. However, objective tumor regressions following intratumoral (IT) BCG injections were reported, ${ }^{10}$ and enthusiasm persists for BCG as an adjuvant in melanoma vaccines. ${ }^{11}$

Table 1 lists many immunotherapies that have been tested in melanoma patients. Two cytokines with broad immunestimulating effects have received regulatory approval for treating melanoma from the United States Food and Drug Administration (FDA). In 1995, interferon (IFN)- $\alpha$ was approved for the adjuvant treatment of surgically resected, high-risk melanoma. ${ }^{12}$ A pegylated formulation of IFN- $\alpha$ received approval in 2011. ${ }^{13}$ Interleukin (IL)-2 has been used to treat metastatic melanoma since its regulatory approval for treating metastatic renal cell carcinoma in 1992 and received marketing approval for treating metastatic melanoma in 1998. ${ }^{14}$ In 2010, the anti-cytotoxic T-cell antigen-4 (CTLA-4) monoclonal antibody ipilimumab was approved based on
Table I Immunotherapies for melanoma other than vaccines

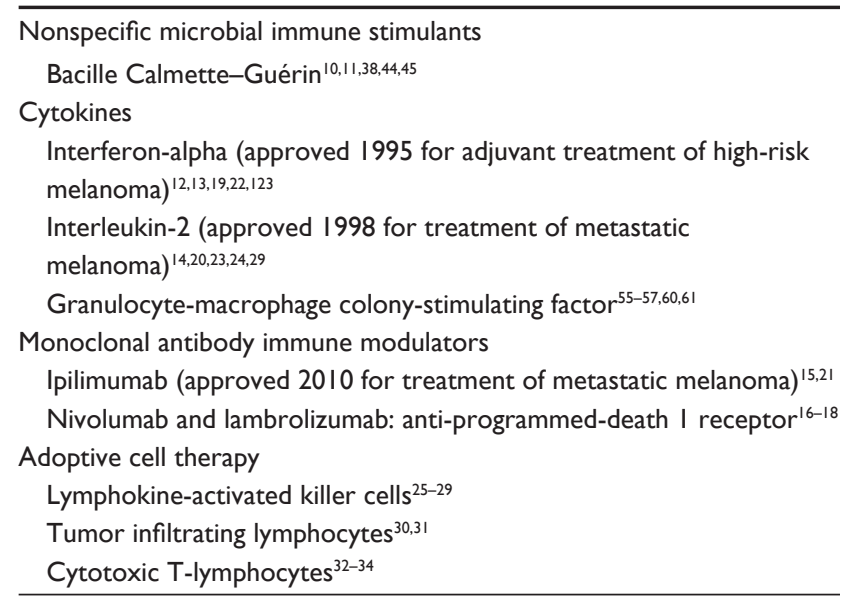

improved survival in patients with metastatic melanoma. ${ }^{15}$ Other immune-modulating products, such as the monoclonal antibodies nivolumab and lambrolizumab that target programmed death receptor-1 (PD-1), ${ }^{16,17}$ and antibodies that target its ligand (PDL-1), ${ }^{18}$ have produced response rates in the range of $25 \%$ to $40 \%$ in melanoma patients. One or more of these anti-PD-1 agents will almost certainly receive regulatory approval in the near future. All of these immunotherapies are nonspecific, and generalized autoimmune effects are responsible for some or all of their antitumor activity and toxicity. For instance, in the adjuvant treatment of high-risk melanoma, serologic detection of autoimmune antibodies induced by IFN- $\alpha$ is the best predictor of progression-free survival. ${ }^{19}$ In patients with metastatic melanoma, autoimmune phenomena such as vitiligo and thyroiditis are associated with clinical benefit of IL-2. ${ }^{20}$ Autoimmune inflammation and associated adverse events are associated with clinical benefit in patients receiving ipilimumab. ${ }^{21}$

Unfortunately, clinical use of available immunotherapy agents is limited because of these toxic side effects. IFN- $\alpha$ commonly induces flu-like symptoms, severe fatigue, and debilitating depression that necessitate cessation of treatment. ${ }^{22}$ Intravenous infusion of high-dose IL-2 induces the release of numerous cytokines that cause severe flu-like symptoms, dermatitis, and potentially lethal capillary leak syndrome associated with hypotension and decreased renal perfusion. ${ }^{23,24}$ For this reason, only a minority of medically fit patients are offered this treatment, which has to be administered in a setting that includes specialized nursing and inpatient monitoring. Ipilimumab is often associated with severe autoimmune toxicities including enterocolitis, dermatitis, and hepatitis, and endocrinopathies such as hypophysitis, thyroiditis, and adrenal insufficiency. ${ }^{21}$ These toxicities 
have resulted in death in some patients. On the other hand, so far the anti-PD-1 antibodies appear to be associated with minimal toxicity. ${ }^{16,17}$

There have been several reports of clinical benefit following adoptive cell therapy with autologous lymphocytes. Early efforts focused on lymphokine-activated killer (LAK) cells that consist of natural killer and T-cells isolated from the peripheral blood and infused with IL-2. ${ }^{25,26}$ Unfortunately, subsequent trials failed to confirm such high response rates, ${ }^{27,28}$ and a randomized trial failed to clearly establish a therapeutic benefit for the addition of LAK cells. ${ }^{29}$ More promising has been the use of tumor-infiltrating lymphocytes (TIL), especially cytotoxic T-lymphocytes (CTL). ${ }^{30,31}$ Immunosuppression by lymphodepletion, followed by IL-2 and infusion of billions of tumor antigen-specific, autologous CTL derived from patient tumor, has resulted in some remarkable therapeutic effects, ${ }^{32,33}$ but may provide no greater clinical benefit than TIL. ${ }^{34}$ Adoption of this approach has been limited by the technical demands of T-cell production, the need for lymphocyte depletion, and infusion of high-dose IL-2.

Immunotherapy may be the most important modality for treating melanoma. However, our current armamentarium has resulted in only modest improvement in the survival of melanoma patients, so more effective and less toxic approaches are needed. It is hoped that vaccine approaches will induce new immune responses or enhance existing weak immune responses, including those partially suppressed by checkpoint molecules and regulatory T-cells. Such vaccine approaches are expected to be additive or synergistic with existing and emerging immunotherapies. Administration of vaccines with ipilimumab may facilitate induction of new anti-melanoma immune responses, while administration of vaccines with anti-PD-1 antibodies may facilitate enhancement of existing anti-melanoma immune responses.

\section{Antigen presentation and complementary agents}

Table 2 lists a number of agents that attract immune cells and/ or enhance immune responses to tumor-associated antigens.

\section{Adjuvants}

Adjuvants that are components of existing FDA-approved vaccines include alum (potassium aluminum sulfate), other aluminum salts (aluminum hydroxide and aluminum phosphate), and ASO4, a mixture of aluminum salts and monophosphoryl lipid A, which is a detoxified component of Salmonella minnesota lipopolysaccharide. ${ }^{35} \mathrm{~A}$ popular adjuvant in animal models is complete Freund's adjuvant, which consists of
Table 2 Antigen presentation and complementary agents

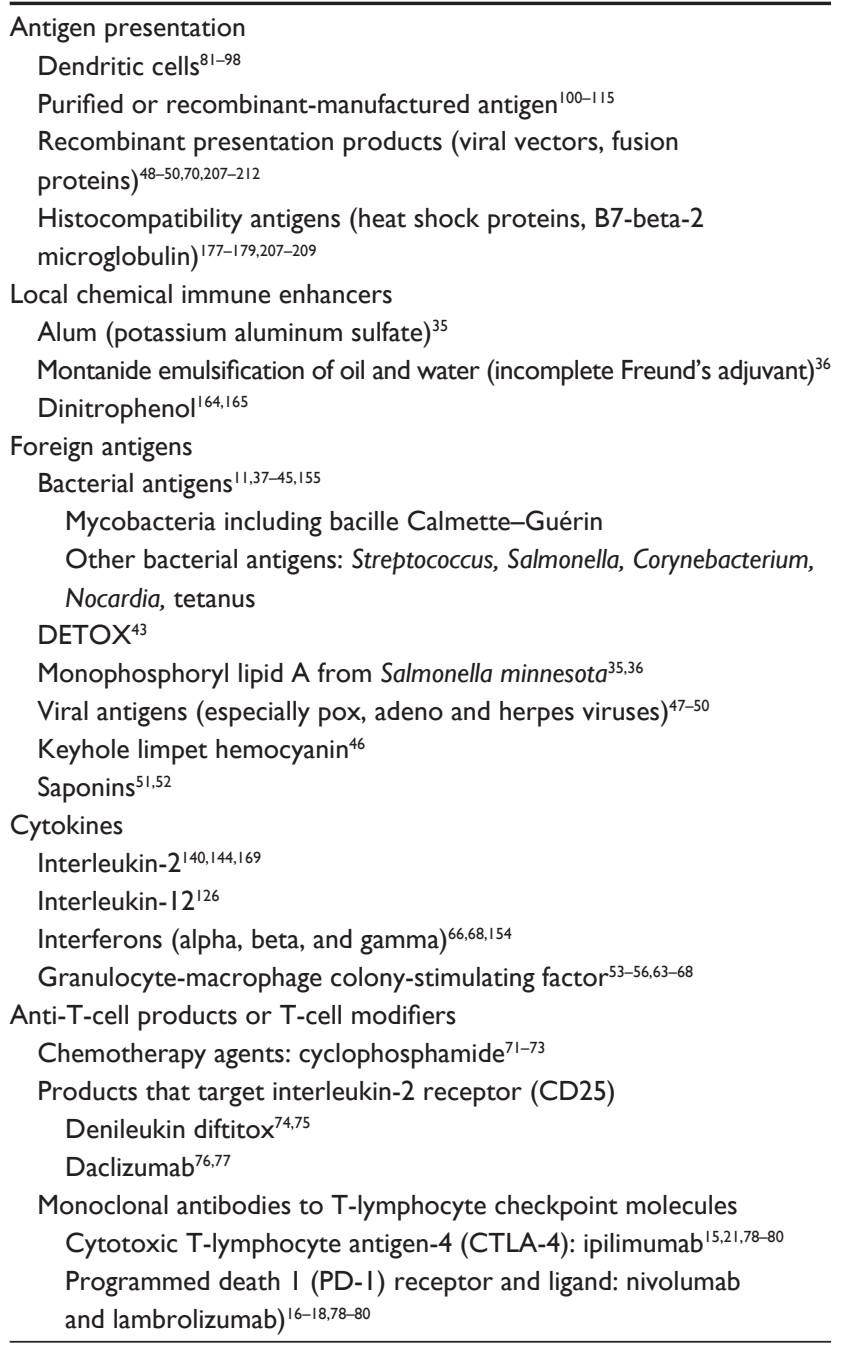

an emulsion of the lipid squalene and water in mineral oil (montanide) and inactivated Mycobacteria tuberculosis, but it is considered too toxic for human use. Incomplete Freund's adjuvant, also known as montanide, lacks the mycobacterial component, and has been used as a component of several investigational melanoma vaccines. ${ }^{36}$ The immune-stimulating effects of bacterial antigens, and their potential to act as adjuvants in vaccines, has been recognized since the description of Coley's toxins. ${ }^{37}$ BCG has been widely used as a bacterial adjuvant and also as a monotherapy. ${ }^{10,11,38-40}$ Proteins from Nocardia, Corynbacteria, Streptococci, Salmonella, and others have also been used. ${ }^{40-44}$ DETOX consists of detoxified endotoxin, MPL, and Mycobacteria minnesota cell wall skeletons ${ }^{45}$ Keyhole limpet hemocyanin (KLH) is a highly immunogenic copper-containing metalloprotein isolated from the giant keyhole limpet Megathura crenulata found along the California seacoast. ${ }^{46}$ Because of immunogenicity of various pox viruses, there has been long-standing interest 
in vaccinia (smallpox) as an adjuvant in viral oncolysates ${ }^{47}$ and, more recently, in recombinant delivery systems that combine viral and tumor antigens. ${ }^{48-50}$ Saponin adjuvants, such as QS-21, are mixtures of soluble triterpene glycosides purified from the South American tree Quillaja saponaria Molina, also known as the soap bark tree. ${ }^{51} \mathrm{ASO} 2{ }_{\mathrm{B}}$ combines MPA and QS21, while AS15 adds synthetic oligonucleotides containing CpG motifs that target Toll-like receptor 9 to the MPL and QS-21.52

\section{Granulocyte-macrophage colony-stimulating factor (GM-CSF)}

Immune-enhancing cytokines may function as adjuvants. ${ }^{53}$ IFN- $\alpha$, IFN- $\gamma$, IL-2, and GM-CSF have been commercially available for more than 20 years, which has facilitated their testing in conjunction with vaccines $;{ }^{54} \mathrm{GM}-\mathrm{CSF}$ has been especially popular. ${ }^{55,56}$ In standard doses, GM-CSF is associated with mild side effects, and it has stimulating effects on DC and B- and T-lymphocytes. It has been given by either injection, cell transfection, or as a component of engineered fusion products. Adjuvant GM-CSF has been associated with antigen-specific immune responses to various melanoma peptide antigens. ${ }^{57-59}$ Phase II trials suggest that maintenance GM-CSF monotherapy may enhance survival in melanoma patients with deep melanomas or positive microscopic regional lymph nodes. ${ }^{60,61}$ In trials in which melanoma patients were treated with patient-specific vaccines, the 53-patient subset that received GM-CSF and/or IFN- $\gamma$ had better survival than 21 patients who received vaccine with no adjuvant, $\mathrm{BCG}$, or IFN- $\alpha$ (3-year survival $29 \%$ versus [vs] $0 \%, P<0.001){ }^{62}$

The benefits of GM-CSF have been questioned by some. ${ }^{63}$ As summarized in Table 3, some randomized trials have been

Table 3 Randomized trials in melanoma testing the cytokine GM-CSF as an immune stimulant

\begin{tabular}{|c|c|c|c|c|c|c|c|}
\hline Author & Stage $^{213}$ & $\begin{array}{l}\text { Number } \\
\text { of patients }\end{array}$ & Antigen & Adjuvant & Route & Clinical efficacy & Other metrics \\
\hline $\begin{array}{l}\text { Weber } \\
\text { et al }{ }^{64}\end{array}$ & II & 20 & $\begin{array}{l}\text { gp } 100 \\
\text { Tyrosinase }\end{array}$ & $\begin{array}{l}\text { Montanide + } \\
\text { GM-CSF }\end{array}$ & SC & $\begin{array}{l}\text { Unclear } \\
<2 \text {-year F/U }\end{array}$ & $\begin{array}{l}\text { Slightly better immune } \\
\text { responses to antigens (NSD) }\end{array}$ \\
\hline $\begin{array}{l}\text { Weber } \\
\text { et al }{ }^{64}\end{array}$ & II & 21 & $\begin{array}{l}\text { gp } 100 \\
\text { Tyrosinase }\end{array}$ & Montanide & SC & $\begin{array}{l}\text { Unclear } \\
<2 \text {-year F/U }\end{array}$ & \\
\hline $\begin{array}{l}\text { Slingluff } \\
\text { et al }{ }^{65}\end{array}$ & $\begin{array}{l}\text { U-III } \\
\text { U-IV }\end{array}$ & 13 & $\begin{array}{l}\text { gp } 100 \\
\text { Tyrosinase }\end{array}$ & $\begin{array}{l}\text { GM-CSF } \\
\text { Montanide } \\
\text { THP } \\
\text { LD IL-2 }\end{array}$ & $\begin{array}{l}\mathrm{SC} \text { and } \\
\mathrm{ID}\end{array}$ & $\begin{array}{l}2 / 13 \mathrm{RR} \\
2 / 13 \text { vitiligo }\end{array}$ & $\begin{array}{l}\text { More antigen specific T-cell } \\
\text { responses }(P=0.02)\end{array}$ \\
\hline $\begin{array}{l}\text { Slingluff } \\
\text { et al }{ }^{65}\end{array}$ & $\begin{array}{l}\text { U-III } \\
\text { U-IV }\end{array}$ & 13 & $\begin{array}{l}\text { gpl00 } \\
\text { Tyrosinase }\end{array}$ & $\begin{array}{l}\text { DC } \\
\text { THP } \\
\text { LD IL-2 }\end{array}$ & $\begin{array}{l}\text { SC and } \\
\text { ID }\end{array}$ & $\begin{array}{l}\text { I/I3 RR } \\
0 / 13 \text { vitiligo }\end{array}$ & \\
\hline $\begin{array}{l}\text { Dillman } \\
\text { et al }{ }^{66}\end{array}$ & $\begin{array}{l}\text { U-III } \\
\text { and IV }\end{array}$ & 25 & $\begin{array}{l}\text { Autologous } \\
\text { tumor cell } \\
\text { lines }\end{array}$ & GM-CSF & SC & $\begin{array}{l}\text { I/IO RR } \\
\text { I5-month med OS } \\
31 \% 5 \text {-year OS }\end{array}$ & $\begin{array}{l}22 \% \text { DTH-T conversion } \\
\text { NSD }\end{array}$ \\
\hline $\begin{array}{l}\text { Dillman } \\
\text { et al }{ }^{66}\end{array}$ & $\begin{array}{l}\text { U-III } \\
\text { and IV }\end{array}$ & 26 & $\begin{array}{l}\text { Autologous } \\
\text { tumor cell } \\
\text { lines }\end{array}$ & $\mathrm{IFN}-\gamma$ & SC & $\begin{array}{l}0 / 10 \text { RR } \\
21 \text {-month med OS } \\
31 \% 5 \text {-year OS }\end{array}$ & $\begin{array}{l}27 \% \text { DTH-T conversion } \\
\text { NSD }\end{array}$ \\
\hline $\begin{array}{l}\text { Faries } \\
\text { et } \text { al }^{67}\end{array}$ & $\begin{array}{l}\text { II } \\
\text { R-III } \\
\text { R-IV }\end{array}$ & 46 & $\begin{array}{l}\text { Allogeneic } \\
\text { tumor cell } \\
\text { lines }\end{array}$ & $\begin{array}{l}\text { GM-CSF } \\
\text { BCG }\end{array}$ & ID & $\begin{array}{l}60 \% 4 \text {-year OS } \\
P=0.10\end{array}$ & $\downarrow$ DTH-V, $P=0.006$ \\
\hline $\begin{array}{l}\text { Faries } \\
\text { et } \text { al }^{67}\end{array}$ & $\begin{array}{l}\text { II } \\
\text { R-III } \\
\text { R-IV }\end{array}$ & 48 & $\begin{array}{l}\text { Allogeneic } \\
\text { tumor cell } \\
\text { lines }\end{array}$ & BCG & ID & $80 \%$ 4-year OS & \\
\hline $\begin{array}{l}\text { Kirkwood } \\
\text { et } \mathrm{al}^{68}\end{array}$ & IV & 56 & $\begin{array}{l}\text { gpl00 } \\
\text { Mart-I } \\
\text { Tyrosinase }\end{array}$ & $\begin{array}{l}\text { GM-CSF } \pm \\
\text { IFN- } \alpha\end{array}$ & SC & $\begin{array}{l}\text { I4.3-month med OS } \\
\approx 28 \% 2 \text {-year OS }\end{array}$ & NSD \\
\hline $\begin{array}{l}\text { Kirkwood } \\
\text { et } \mathrm{al}^{68}\end{array}$ & IV & 61 & $\begin{array}{l}\text { gpl00 } \\
\text { Mart-I } \\
\text { Tyrosinase }\end{array}$ & None or IFN- $\alpha$ & SC & $\begin{array}{l}\text { 10.4-month med OS } \\
\approx 26 \% 2 \text {-year OS }\end{array}$ & \\
\hline $\begin{array}{l}\text { Lawson } \\
\text { et al }{ }^{69}\end{array}$ & $\begin{array}{l}\text { R-III } \\
\text { R-IV }\end{array}$ & $\approx 400$ & None & GM-CSF & SC & $\begin{array}{l}\text { 12-month med DFS } \\
\text { 72-month med OS }\end{array}$ & $\begin{array}{l}P=0.14 \\
P=0.55\end{array}$ \\
\hline $\begin{array}{l}\text { Lawson } \\
\text { et al }{ }^{69}\end{array}$ & $\begin{array}{l}\text { R-III } \\
\text { R-IV }\end{array}$ & $\approx 400$ & None & Placebo & SC & $\begin{array}{l}\text { 9-month med DFS } \\
\text { 60-month med OS }\end{array}$ & \\
\hline
\end{tabular}

Abbreviations: BCG, bacille Calmette-Guérin; DFS, disease-free survival; DTH-T, delayed-type hypersensitivity reaction to tumor cells; DTH-V, delayed-type hypersensitivity reaction to vaccine; F/U, follow-up; GM-CSF, granulocyte-macrophage colony-stimulating factor; ID, intradermal; IFN, interferon; IL, interleukin; LD, low-dose; med, median; NSD, no significant difference; OS, overall survival; R, resected; RR, response rate; SC, subcutaneous; THP, tetanus helper peptide; U, unresectable; DC, dendritic cells. 
conducted to better define the role of GM-CSF in vaccines, but none were definitive. ${ }^{64-69}$ The largest (ECOG 4697) is an intergroup trial for which interim results have been presented in abstract form. ${ }^{69}$ Patients who were HLA-A2 positive were randomized to gp100 vaccine or placebo with a secondary randomization to GM-CSF or placebo, while HLA-A2negative patients were randomized to GM-CSF or placebo. The interim analysis found no advantage for GM-CSF, but among 258 patients with stage IV disease, there was a trend toward improved disease-free survival and overall survival.

In addition to injection of various adjuvants, molecular and transfection techniques make it possible to create a variety of combinations and permutations of antigens and immune-stimulating proteins. For instance, a fusion protein of GM-CSF and prostatic acid phosphatase was the basis for the immune therapy sipuleucel-T that was recently approved for the treatment of prostate cancer. ${ }^{70}$

\section{T-cell-mediated immune modifiers}

T-lymphocytes provide oversight of the immune system to protect against debilitating autoimmune responses. In addition to helper, memory, and suppressor T-cells, there are also regulatory $\mathrm{T}(\mathrm{CD} 4+\mathrm{CD} 45+$ FoxP3+)-cells that inhibit interactions between DC and T-lymphocytes. A few small trials have explored the immune-modulating effects of anti-T-lymphocyte agents such as cyclophosphamide chemotherapy, ${ }^{71-73}$ the anti-CD25 immunotoxin denileukin diftitox, ${ }^{74,75}$ and the anti-CD25 monoclonal antibody daclizumab. $^{76,77}$ Whether addition of these agents can enhance vaccine therapy remains to be seen. There is great optimism for the role of antibodies that target T-cell checkpoint molecules, including CTLA-4, PD-1, and its ligand PDL$1,{ }^{78-80}$ not only as monotherapies but as adjuncts to vaccine therapies. CTLA-4 inhibits induction of T-cell-mediated immunity by competing with the CD28 receptor on T-cells that binds to dendritic cells via CD80 and CD86. PDL-1, which is present at sites of inflammation and is produced by many tumors, induces apoptosis of antigen-activated T-cells by binding to their PD-1 receptors. As single agents in patients with relapsed melanoma, the anti-PD-1 monoclonal antibodies nivolumab and lambrolizumab have produced objective response rates of $28 \%$ to $38 \%{ }^{16,17}$ Ipilimumab was associated with a response rate of less than $15 \%$, but provided a survival benefit in a randomized, placebo-controlled trial. ${ }^{15}$ However, immunization with gp 100 provided no additional benefit beyond ipilimumab alone. Trials that combine other vaccines with these monoclonal antibodies will be forthcoming.

\section{$\mathrm{DC}$}

DC are now recognized as the most important of the antigenpresenting cells. ${ }^{81-83}$ They can be derived from bone marrow or peripheral blood mononuclear cells. Immature DC are preferred for antigen-loading, but the subsequent maturation is crucial for antigen presentation. ${ }^{84-86}$ Although apoptotic tumor cells may be associated with tolerance in the tumor microenvironment, ${ }^{87,88}$ apoptotic rather than necrotic cells are preferred for ex vivo DC loading. ${ }^{89}$ Of practical importance for manufacturing, studies have shown that DC are phenotypically and functionally similar before freezing and after thawing. ${ }^{90,91}$ Even though few DC actually reach regional lymph nodes after injections, it only takes a small number migrating there to induce a robust immune response against new antigens. ${ }^{92}$ DC produced using different manufacturing conditions may differ biologically and functionally. ${ }^{93}$ Since the earliest reports of tumor response after injections of DC pulsed with autologous tumor lysate or melanoma-associated antigen (MAA) peptides,${ }^{94} \mathrm{DC}$ have been used to present a variety of MAA as part of vaccine investigation. ${ }^{95-98}$

\section{Other variables in vaccine delivery}

Another variable for melanoma vaccines is route of administration. Possibilities include intranodal (IN), intralymphatic (ILY), IT, intravenous (IV), subcutaneous (SC), intradermal (ID), intramuscular (IM), and combinations of these. There is no convincing evidence that there is a preferred route, ${ }^{99}$ but SC and IM are most practical in terms of ease of administration and the volume of vaccine that can be administered while avoiding the risks of toxicity associated with IV administration. For a variety of different reasons, including production limitations and study power, vaccine trials have failed to define minimally effective doses, maximum tolerated doses, or optimum doses or dose ranges of antigen exposure. There is also no convincing evidence that there is a preferred schedule of administration. Daily, weekly, and monthly approaches have been used as well as combinations of the above with different induction and booster or maintenance schedules. The optimal duration of vaccine therapy is also unclear and can only be tested when a vaccine has been validated to be therapeutically beneficial.

\section{Melanoma antigens and clinical trials}

Table 4 summarizes various antigen sources that have been or are being tested in clinical trials. The rest of this review focuses on these antigens and results of clinical trials, especially randomized trials. 
Table 4 Sources of melanoma-associated antigens for therapeutic vaccines

Melanoma-associated antigens identified by monoclonal antibodies ${ }^{100-110}$ Melanoma-associated antigens identified by cytotoxic T-cells ${ }^{111-115}$

Anti-idiotype antibodies mimicking melanoma antigen ${ }^{106,109,118,119}$

Allogeneic tumor cell lines ${ }^{149-155}$

Autologous tumor ex vivo 162-169,177-179,201-212

Autologous tumor cell lines ${ }^{62,180,181,191-200}$

\section{Characterized MAA}

Murine monoclonal antibodies, human antitumor antibodies, and human CTL from patients responding to TIL therapy have identified numerous MAA that could be targeted for therapy. The first MAA were identified by murine monoclonal antibodies and included high-molecular-weight chondroitin sulfate proteoglycan (gp225), also known as human highmolecular-weight-melanoma-associated antigen (HMWMAA); ${ }^{100,101}$ gp97 melanotransferrin; ${ }^{100,101}$ gangliosides; ${ }^{102}$ including GM2, ${ }^{103,104} \mathrm{GM} 3,{ }^{105} \mathrm{GD} 2,{ }^{106,107}$ and GD3; ${ }^{108,109}$ and other antigens of various molecular weights. ${ }^{110} \mathrm{HMW}-\mathrm{MAA}$ is expressed on $80 \%$ of melanomas and is believed to activate several signaling cascades that affect cell adhesion, migration, and invasion. An increasing number of different melanoma peptide antigens have been recognized by CTL; examples are Mage-1, Mage-3, Mart-1 (Melan-A), tyrosinase, gp100, and NY-Eso-1. ${ }^{11-115}$ These may be classified as oncofetal or cancer testis antigens, or as melanocyte differentiation antigens. Oncofetal antigens include the melanoma gene families referred to as A-MAAs (Mage, including Mage-A1, Mage-A3, and Mage-A4), B-MAAs (Bage) and G-MAAs (Gage), and NY-Eso-1. Many of these are HLA-phenotype restricted, none are expressed on all melanoma tumor cells, and many are expressed on less than $50 \%$ of tumor samples. Melanocyte differentiation antigens involved in melanin production include tyrosinase, gp100 (recognized by HMB45) and Melan-A (Mart-1), and tyrosine-related protein-2 (TRP-2). Many unique antigens have been detected that result from mutations or aberrant expression on malignant cells. In addition to being tumor-specific MAA, some may function as oncogenes, inhibit suppressor genes, induce angiogenesis, cause cell cycle dysregulation, alter epigenetic regulation, and increase resistance to apoptosis. Examples include multiple myeloma oncogene-1 (MUM-1), which is normally involved in immunoglobulin gene expression in B-cells; cyclin-dependent kinase 4 (CDK4) that leads to dysregulated cell cycle activity; p15, which normally inhibits CDK4, the cell adhesion molecule beta-catenin; $\mathrm{N}$-acetylglucosaminyltransferase $\mathrm{V}$, which can be upregulated by transforming growth factor-beta; variants of gp100; fatty acid-binding protein-7; and homeobox (HOX) transcription factors involved in protein regulation. In one study, Mage-1 and Mage-4 were more likely to be expressed on sites of metastatic disease than primary melanoma, while NY-Eso-1 was expressed on about $45 \%$ of both sites. ${ }^{116}$ Patients with pre-existing T-lymphocytes that recognize Melan-A and NY-Eso-1 have a better prognosis than patients who lack such T-cells. ${ }^{117}$ Mage-1 and Mage-3 are HLA-A1-restricted, while Mart-1 (Melan-A), tyrosinase, and gp100 are HLAA2-restricted, which limits their testing to specific patient populations.

Trials with MAA recognized by murine monoclonal antibodies and/or gangliosides are summarized in Table $5 .{ }^{118-123} \mathrm{~A}$ construct consisting of recombinant vaccinia virus and $\mathrm{p} 97$ (melanotransferrin) called v-p97NY appeared promising in mouse models, but apparently was not evaluated further. ${ }^{124}$ The mouse anti-idiotype monoclonal antibody MK2-23 mimics HMW-MAA. ${ }^{118}$ The product TriGem ${ }^{\mathrm{TM}}$ (Titan Pharmaceuticals, South San Francisco, CA, USA) consisted of anti-idiotype antibody-mimicking GD2 mixed with QS-21. ${ }^{106}$ One anti-GM3 vaccine consists of N-glycolylneuraminyllactosylceramide (NeuGcGM3) in a proteoliposome of Neisseria meningitides with Montanide ${ }^{\mathrm{TM}}$ ISA (SEPPIC Fairfield, NJ, USA). ${ }^{120}$ The anti-GD3 anti-idiotype BEC2 was used to create the GD3-lactone-KLH/QS21 product. ${ }^{121}$ In randomized trials, the GM2-BCG vaccine was not clearly superior to $\mathrm{BCG}$ alone, ${ }^{122}$ and a trial comparing a GM-2 vaccine to high-dose IFN- $\alpha$ was stopped after only 16 months' median follow-up when an interim analysis showed it was inferior to IFN- $\alpha .{ }^{123}$ In summary, trials of ganglioside antigens have not been associated with high response rates or survival benefit in patients with metastatic disease,,${ }^{118,119}$ have not been associated with encouraging disease-free or overall survival rates in patients with resected disease, ${ }^{121,122}$ and were inferior to IFN- $\alpha$ in a large, randomized trial in patients with resected high-risk stage II and III disease. ${ }^{123}$

There was great interest in testing peptide MAA recognized by CTL from patients who had responded to TIL treatment. ${ }^{111}$ Numerous trials have been reported that used melanoma peptide antigens with various adjuvants or loaded on DC (Table 6). ${ }^{59,94,124-139}$ These trials varied in terms of disease stage, whether or not tumor had been resected prior to treatment, and the use of adjuvants and immune modifiers. They confirmed that immunization with such peptides could induce or enhance antigen-specific T-cell responses to various MAA, but there were no striking differences related to different adjuvants or antigen-delivery by DC. Even though 
Table 5 Single-arm and randomized trials involving ganglioside antigens

\begin{tabular}{|c|c|c|c|c|c|c|c|}
\hline Author & Stage $\mathrm{e}^{213}$ & $\begin{array}{l}\text { Number } \\
\text { of patients }\end{array}$ & Antigen & $\begin{array}{l}\text { Adjuvant } \\
\text { or modifier }\end{array}$ & Route & Clinical efficacy & Other metrics \\
\hline $\begin{array}{l}\text { Mittelman } \\
\text { et al }{ }^{118}\end{array}$ & $\begin{array}{l}\text { U-III } \\
\text { IV }\end{array}$ & 52 & $\begin{array}{l}\text { HMW-MAA } \\
\text { (anti-id) }\end{array}$ & $\begin{array}{l}\text { None, CTX, KLH, } \\
\text { BCG }\end{array}$ & SC & 4.4-month med OS & $\begin{array}{l}3 / 52 \text { made antigen } \\
\text { specific antibodies }\end{array}$ \\
\hline $\begin{array}{l}\text { Foon } \\
\text { et al }{ }^{119}\end{array}$ & IV & 47 & $\begin{array}{l}\text { GD2 } \\
\text { (anti-id) }\end{array}$ & QS-2I & SC & $\begin{array}{l}\text { I/47 RR, CR } \\
\text { I6-month med OS }\end{array}$ & $\begin{array}{l}\text { 40/47 made anti-GD2 } \\
\text { antibodies }\end{array}$ \\
\hline $\begin{array}{l}\text { Osorio } \\
\text { et al }{ }^{120}\end{array}$ & R-IV & 35 & $\begin{array}{l}\text { NeuGcGM3 } \\
\text { ganglioside }\end{array}$ & $\begin{array}{l}\text { Neisseria and } \\
\text { Montanide in liposome }\end{array}$ & SC & $\begin{array}{l}\text { 5/35 RR, } 2 \text { CR } \\
\text { 20-month med OS }\end{array}$ & $\begin{array}{l}\text { 28/30 made anti-GM3 } \\
\text { antibodies }\end{array}$ \\
\hline $\begin{array}{l}\text { Chapman } \\
\text { et al }\left.\right|^{\mid 21}\end{array}$ & $\begin{array}{l}\text { R-III } \\
\text { R-IV }\end{array}$ & 12 & $\begin{array}{l}\mathrm{GD} 3 \rightarrow \mathrm{GD} 3 \\
\text { anti-id }\end{array}$ & $\begin{array}{l}\mathrm{KLH}+\mathrm{QS}-2 \mathrm{I} \\
\mathrm{BCG}\end{array}$ & ID & $\begin{array}{l}\text { 45-month med OS for } \\
\text { all patients (22/24 R-III) }\end{array}$ & $\begin{array}{l}5 / 12 \text { made anti-GD3 } \\
\text { antibodies }\end{array}$ \\
\hline $\begin{array}{l}\text { Chapman } \\
\text { et al }{ }^{|2|}\end{array}$ & $\begin{array}{l}\text { R-III } \\
\text { R-IV }\end{array}$ & 12 & $\begin{array}{l}\text { GD3 } \\
\text { anti-id } \rightarrow \text { GD3 }\end{array}$ & $\begin{array}{l}\text { BCG } \\
K L H+Q S-2 I\end{array}$ & ID & $\begin{array}{l}\text { No difference } \\
\text { for sequence }\end{array}$ & $\begin{array}{l}5 / 12 \text { made anti-GD3 } \\
\text { antibodies }\end{array}$ \\
\hline $\begin{array}{l}\text { Livingston } \\
\text { et al }{ }^{122}\end{array}$ & R-IV & 58 & GM-2 & $\mathrm{BCG}$ & ID & $\begin{array}{l}70 \% 2 \text {-year OS } \\
60 \% 3 \text {-year OS } \\
P=0.22\end{array}$ & $\begin{array}{l}\text { 50/58 made anti-GM2 } \\
\text { antibodies }\end{array}$ \\
\hline $\begin{array}{l}\text { Livingston } \\
\text { et al }\left.\right|^{122}\end{array}$ & $\begin{array}{l}\text { R-III } \\
\text { R-IV }\end{array}$ & 64 & None & BCG & ID & $\begin{array}{l}70 \% \text { 2-year OS } \\
45 \% \text { 3-year OS }\end{array}$ & $\begin{array}{l}7 / 64 \text { made anti-GM2 } \\
\text { antibodies }\end{array}$ \\
\hline $\begin{array}{l}\text { Kirkwood } \\
\text { et al }{ }^{123}\end{array}$ & $\begin{array}{l}\text { R-II } \\
\text { R-III }\end{array}$ & 440 & GM-2 & KLH, QS-2I & ID & $\begin{array}{l}51 \% 2 \text {-year DFS } \\
73 \% 2 \text {-year OS }\end{array}$ & $\begin{array}{l}\text { DFS } \\
P=0.0015\end{array}$ \\
\hline $\begin{array}{l}\text { Kirkwood } \\
\text { et al }{ }^{123}\end{array}$ & $\begin{array}{l}\text { R-II } \\
\text { R-III }\end{array}$ & 440 & None & HD-IFN- $\alpha$ & ID & $\begin{array}{l}55 \% \text { 2-year DFS } \\
78 \% 2 \text {-year OS }\end{array}$ & $\begin{array}{l}\text { OS } \\
P=0.009\end{array}$ \\
\hline
\end{tabular}

Abbreviations: anti-id, anti-idiotype; BCG, bacille Calmette-Guérin; CR, complete response; CTX, cyclophosphamide; DFS, disease-free survival; HD, high-dose; HMW-MAA, high-molecular-weight melanoma-associated antigen; ID, intradermal; IFN, interferon; KLH, keyhole limpet hemocyanin; med, median; OS, overall survival; $\mathrm{R}$, resected; RR, response rate; SC, subcutaneous; $U$, unresectable.

antigen-specific responses were detected in many patients, antitumor responses with vaccine monotherapy occurred in less than $10 \%$ of patients with measurable disease. The $10 \%$ response rate for DC-based approaches ${ }^{94,130,134,137,138}$ was not statistically higher $(10 / 97$ vs $10 / 174, P=0.17)$ than the $6 \%$ response rate for non-DC approaches ${ }^{125,126,131-133,136,139} \mathrm{The} 9 \%$ response rate for multivalent vaccines ${ }^{94,130,133,134,137-139}$ was not statistically higher $(15 / 165$ vs $5 / 106, P=0.18)$ than the $5 \%$ response rate for monovalent vaccines. ${ }^{125,126,131,132}$ The $6 \%$ response rate for vaccines containing Mage- $3^{131-133,137-139}$ was not dissimilar $(9 / 150$ vs $11 / 121, P=0.33)$ to the $9 \%$ response rate for vaccines that did not contain Mage-3. ${ }^{94,125,126,130,134,136}$ The objective response rate following IL-2 historically was about $17 \%,{ }^{14}$ and was still $17 \%$ despite the addition of gp100. ${ }^{129}$ Disease recurrence was still high in patients with advanced disease who were disease-free at the time of vaccination, and survival was influenced more by patient selection than by vaccine therapy. The importance of patient selection is evidenced by the $45 \% 5$-year survival rate for patients treated by complete surgical resection of metastatic melanoma just prior to treatment with any of several peptide vaccines. ${ }^{135}$

Table 7 summarizes randomized trials that tested peptide vaccines: $;^{15,73,140-144}$ only two were powered to compare treatment arms in a Phase III trial. ${ }^{15,144}$ Again, these trials vary in terms of disease stage, antigens, adjuvants, and other immune modifiers. None of the smaller Phase II trials showed definitive differences between or among study arms, although trends were used to select products for further investigation. It is noteworthy that stage IV patients treated with DC loaded with a combination of peptide antigens did no worse than patients treated with dacarbazine, but the vaccine was less toxic. ${ }^{141}$ In the largest trial, gp100 did not add benefit to ipilimumab in patients with measurable stage IV disease, ${ }^{15}$ but, in a much smaller trial, gp100 appeared to add benefit to patients who were healthy enough to receive high-dose IL-2, ${ }^{144}$ although the response rate to IL-2 alone was much lower than the $17 \%$ reported in trials. ${ }^{14,129}$

It is hoped that oncofetal peptide MAA will produce more striking results because of their frequent expression on tumor stem cells. In 25 melanoma patients ( $72 \%$ stage IV and $28 \%$ stage III), preexisting anti-NY-Eso-1 CD4+ and CD8+ cells were present in $52 \%$ and $40 \%$, respectively, before vaccination, but increased to $78 \%$ and $88 \%$ after vaccination with recombinant vaccinia and fowlpox vectors expressing NY-Eso-1 antigen. ${ }^{145}$ The objective tumor response rate was $3 / 21$ and median survival 48 months for all 25 patients. However, the major clinical benefit was in patients who already had preexisting antibody and T-cell recognition of NY-Eso-1, and the presence of preexisting anti-NY-Eso- 1 antibodies was more predictive of survival than induction of anti-NY-Eso-1 antibodies after immunization. Several trials with NY-Eso-1 and other oncofetal antigens are in progress.

A Mage-A3 antigen-specific cancer immunotherapeutic (ASCI) product is being tested in combination with the AS15 
Table 6 Single-arm trials testing peptide vaccines and other agents

\begin{tabular}{|c|c|c|c|c|c|c|c|}
\hline Author & Stage $^{213}$ & $\begin{array}{l}\text { Number } \\
\text { of patients }\end{array}$ & Antigen & $\begin{array}{l}\text { Adjuvant } \\
\text { or modifier }\end{array}$ & Route & Clinical efficacy & Other metrics \\
\hline $\begin{array}{l}\text { Cormier } \\
\text { et al }\end{array}$ & IV & 23 & $\begin{array}{l}\text { Melan-A/ } \\
\text { Mart-I }\end{array}$ & Montanide & SC & $0 / 23 R R$ & $\begin{array}{l}\text { Increased antigen- } \\
\text { specific cytotoxicity }\end{array}$ \\
\hline $\begin{array}{l}\text { Peterson } \\
\text { et al }{ }^{126}\end{array}$ & IV & 20 & $\begin{array}{l}\text { Melan-A/ } \\
\text { Mart-I }\end{array}$ & $\begin{array}{l}\text { PBMC } \\
\text { IL-I2 }\end{array}$ & SC & $\begin{array}{l}\text { 2/20 RR, } 2 \text { CR } \\
\text { 12-month med OS }\end{array}$ & $\begin{array}{l}\text { Increased antigen- } \\
\text { specific T-cell response }\end{array}$ \\
\hline $\begin{array}{l}\text { Smith } \\
\text { et al }{ }^{127}\end{array}$ & $\begin{array}{l}\text { I-II } \\
\text { R-III }\end{array}$ & 30 & gp 100 & Montanide & SC & No data & $\begin{array}{l}\text { 28/29 increased antigen- } \\
\text { specific T-cell responses }\end{array}$ \\
\hline $\begin{array}{l}\text { Rosenberg } \\
\text { et al }{ }^{128}\end{array}$ & $\begin{array}{l}\text { II } \\
\text { R-III } \\
\text { R-IV }\end{array}$ & 95 & gPI00 & Montanide & SC & $\approx 50 \% 3$-year DFS & $\begin{array}{l}\text { High levels of antigen- } \\
\text { specific T-cell responses }\end{array}$ \\
\hline $\begin{array}{l}\text { Sosman } \\
\text { et al }{ }^{129}\end{array}$ & IV & $|3|$ & gp 100 & HD-IL-2 & SC & $\begin{array}{l}20 / I 2 \text { I RR } \\
\text { I5-month med OS } \\
\approx 35 \% \text { 2-year OS }\end{array}$ & $\begin{array}{l}\text { No clinical correlation } \\
\text { with antigen-specific } \\
\text { responses }\end{array}$ \\
\hline $\begin{array}{l}\text { Lesterhuis } \\
\text { et } \mathrm{al}^{130}\end{array}$ & IV & 27 & $\begin{array}{l}\text { gp } 100 \\
\text { Tyrosinase }\end{array}$ & $\begin{array}{l}\mathrm{DC} \\
\mathrm{KLH}\end{array}$ & $\begin{array}{l}\text { IV } \\
\text { and ID }\end{array}$ & $2 / 27 R R$ & $\begin{array}{l}3 / 27 \text { antigen-specific } \\
\text { responses }\end{array}$ \\
\hline $\begin{array}{l}\text { Marchand } \\
\text { et al }{ }^{|3|}\end{array}$ & IV & 33 & Mage-3 & $\begin{array}{l}\text { MPL } \\
\text { QS-2I }\end{array}$ & IM & $2 / 33 R R$ & \\
\hline $\begin{array}{l}\text { Kruit } \\
\text { et al }{ }^{132}\end{array}$ & IV & 30 & Mage-3 & $\begin{array}{l}\text { Haemophilus } \\
\text { influenzae protein D }\end{array}$ & $\begin{array}{l}\text { SC } \\
\text { and ID }\end{array}$ & I/30 RR & $\begin{array}{l}\text { Rare antigen-specific } \\
\text { responses }\end{array}$ \\
\hline $\begin{array}{l}\text { van Baren } \\
\text { et al }\left.\right|^{133}\end{array}$ & IV & 37 & $\begin{array}{l}\text { Mage-1 } \\
\text { Mage-3 }\end{array}$ & Canary pox & $\begin{array}{l}\text { SC } \\
\text { and ID }\end{array}$ & I/30 RR & \\
\hline $\begin{array}{l}\text { Nestle } \\
\text { et } \mathrm{al}^{94}\end{array}$ & IV & 16 & $\begin{array}{l}\text { gPl00 } \\
\text { Melan-A } \\
\text { Tyrosinase or } \\
\text { autologous tumor }\end{array}$ & $\begin{array}{l}\text { DC } \\
\text { KLH }\end{array}$ & IN & $5 / 16(2 \mathrm{CR})$ & $\begin{array}{l}\text { DTH-peptide pulsed } \\
\text { DC II/16 }\end{array}$ \\
\hline $\begin{array}{l}\text { Hersey } \\
\text { et } \mathrm{al}^{134}\end{array}$ & IV & 14 & $\begin{array}{l}\text { gp I00 } \\
\text { Melan-A } \\
\text { Tyrosinase }\end{array}$ & $\begin{array}{l}\mathrm{DC} \text { immature } \\
\mathrm{KLH}\end{array}$ & IN & 0/14 RR & \\
\hline $\begin{array}{l}\text { Atzpodien } \\
\text { and Reitz }\end{array}$ & $\begin{array}{l}\text { II } \\
\text { R-III } \\
\text { R-IV }\end{array}$ & 24 & $\begin{array}{l}\text { gpl00 } \\
\text { Melan-A } \\
\text { Tyrosinase } \\
\text { Mage-I }\end{array}$ & GM-CSF & SC & $\begin{array}{l}<10 \% \text { still } \\
\text { disease-free } \\
\text { at } 2 \text { years }\end{array}$ & 20/24 DTH-V \\
\hline $\begin{array}{l}\text { Tagawa } \\
\text { et al }{ }^{135}\end{array}$ & R-IV & 41 & $\begin{array}{l}\text { Melan A } \\
\text { gpl00 } \\
\text { Tyrosinase }\end{array}$ & $\begin{array}{l}\text { Various } \\
8 \text { different trials }\end{array}$ & SC & $\begin{array}{l}\text { 3.8-year med OS } \\
45 \% 5 \text {-year OS }\end{array}$ & \\
\hline $\begin{array}{l}\text { Tarhini } \\
\text { et al }{ }^{136}\end{array}$ & $\begin{array}{l}\text { U-III } \\
\text { U-IV }\end{array}$ & 22 & $\begin{array}{l}\text { Melan-A } \\
\text { gpl00 } \\
\text { Tyrosinase }\end{array}$ & $\begin{array}{l}\text { Montanide } \\
\text { GM-CSF } \\
\text { mRNA }\end{array}$ & SC & $2 / 2 I R R$ & $\begin{array}{l}9 / 20 \text { antigen-specific } \\
\text { response }\end{array}$ \\
\hline $\begin{array}{l}\text { Banchereau } \\
\text { et al }{ }^{137}\end{array}$ & IV & 22 & $\begin{array}{l}\text { gp I00 } \\
\text { Melan-A } \\
\text { Tyrosinase } \\
\text { Mage-3 }\end{array}$ & $\mathrm{DC} \pm \mathrm{KLH}$ & SC & $\begin{array}{l}\text { 0/22 RR } \\
\text { 12-month med OS }\end{array}$ & $\begin{array}{l}\text { No increase in antigen- } \\
\text { specific T-cell response }\end{array}$ \\
\hline $\begin{array}{l}\text { Hersey } \\
\text { et al }{ }^{138}\end{array}$ & IV & 18 & $\begin{array}{l}\text { gp I00 } \\
\text { Melan-A } \\
\text { Tyrosinase } \\
\text { Mage-3 }\end{array}$ & $\begin{array}{l}\text { DC mature } \pm \\
\text { LD IL-2 }\end{array}$ & IN & $\begin{array}{l}\text { 2/9 RR + IL-2 } \\
\text { I/9 RR no IL-2 } \\
\text { I8-month med OS }\end{array}$ & \\
\hline $\begin{array}{l}\text { Slingluff } \\
\text { et al }{ }^{139}\end{array}$ & $\begin{array}{l}\text { III-B } \\
\text { IV }\end{array}$ & 37 & $\begin{array}{l}6 \text { peptide } \\
\text { Melan-A } \\
\text { gp } 100 \\
\text { Tyrosinase } \\
\text { Mage-3 }\end{array}$ & $\begin{array}{l}\text { GM-CSF } \\
\text { Montanide }\end{array}$ & $\begin{array}{l}\text { SC } \\
\text { and ID }\end{array}$ & $\begin{array}{l}2 / 17 \text { RR } \\
72 \% \text { I.5-year OS }\end{array}$ & $\begin{array}{l}30 / 37 \text { had antigen- } \\
\text { specific T-cell responses }\end{array}$ \\
\hline
\end{tabular}

Abbreviations: CR, complete response; DC, dendritic cells; DFS, disease-free survival; DTH, delayed-type hypersensitivity; DTH-V, DTH reaction to vaccine; GM-CSF, granulocyte-macrophage colony-stimulating factor; HD, high-dose; ID, intradermal; IL, interleukin; IN, intranodal; KLH, keyhole limpet hemocyanin; LD, low-dose; med, median; MPL, monophosphoryl lipid A; mRNA, messenger ribonucleic acid; OS, overall survival; PBMC, peripheral blood mononuclear cells; R, resected; RR, response rate; SC, subcutaneous; $U$, unresectable. 
Table 7 Randomized trials testing peptides and other agents

\begin{tabular}{|c|c|c|c|c|c|c|c|}
\hline Author & Stage $\mathrm{e}^{213}$ & $\begin{array}{l}\text { Number } \\
\text { of patients }\end{array}$ & Antigen & $\begin{array}{l}\text { Adjuvant } \\
\text { or modifier }\end{array}$ & Route & Clinical efficacy & Other metrics \\
\hline Slingluff et al ${ }^{140}$ & $\begin{array}{l}\text { R-IIB } \\
\text { R-III } \\
\text { R-IV }\end{array}$ & 20 & $\begin{array}{l}\text { gp I00 } \\
\text { Tyrosinase }\end{array}$ & $\begin{array}{l}\text { THP } \\
\text { Montanide } \\
\text { GM-CSF } \\
\text { IL-2 day } 7\end{array}$ & $\begin{array}{l}\text { SC } \\
\text { and ID }\end{array}$ & $\begin{array}{l}39 \% \text { 2-year DFS } \\
P=0.32\end{array}$ & $\begin{array}{l}\text { T-cell responses } \\
37 \% \mathrm{PBL} \\
38 \% \mathrm{SLN}\end{array}$ \\
\hline Slingluff et al $\left.\right|^{140}$ & $\begin{array}{l}\text { R-IIB } \\
\text { R-III } \\
\text { R-IV }\end{array}$ & 20 & $\begin{array}{l}\text { gp } 100 \\
\text { Tyrosinase }\end{array}$ & $\begin{array}{l}\text { THP } \\
\text { Montanide } \\
\text { GM-CSF } \\
\text { IL-2 day } 28\end{array}$ & $\begin{array}{l}\text { SC } \\
\text { and ID }\end{array}$ & $\begin{array}{l}50 \% 2 \text {-year DFS } \\
P=0.32\end{array}$ & $\begin{array}{l}\text { T-cell responses } \\
53 \% \mathrm{PBL} \\
83 \% \mathrm{SLN}\end{array}$ \\
\hline $\begin{array}{l}\text { Schadendorf } \\
\text { et al }{ }^{141}\end{array}$ & IV & 53 & $\begin{array}{l}\text { gpl00 } \\
\text { Tyrosinase } \\
\text { Mage-I } \\
\text { Mage-3 }\end{array}$ & $\mathrm{DC}$ & SC & $\begin{array}{l}\text { 2/4I RR } \\
9.3 \text {-month med OS } \\
20 \% 2 \text {-year OS }\end{array}$ & $\begin{array}{l}\text { NSD } \\
P=0.48\end{array}$ \\
\hline $\begin{array}{l}\text { Schadendorf } \\
\text { et al }{ }^{141}\end{array}$ & IV & 55 & None & DTIC & IV & $\begin{array}{l}3 / 52 \text { RR } \\
\text { I.6-month med OS } \\
20 \% \text { 2-year OS }\end{array}$ & $\begin{array}{l}\text { NSD } \\
P=0.48\end{array}$ \\
\hline Slingluff et al ${ }^{142}$ & $\begin{array}{l}\text { R-IIB } \\
\text { R-III } \\
\text { R-IV }\end{array}$ & 26 & $\begin{array}{l}4 \text { peptide } \\
\text { gp } 100 \\
\text { Tyrosinase }\end{array}$ & $\begin{array}{l}\text { THP } \\
\text { Montanide } \\
\text { GM-CSF }\end{array}$ & $\begin{array}{l}\text { SC } \\
\text { and ID }\end{array}$ & $\begin{array}{l}\text { Med DFS and OS } \\
\text { not provided }\end{array}$ & \\
\hline Slingluff et $\mathrm{al}^{142}$ & $\begin{array}{l}\text { R-IIB } \\
\text { R-III } \\
\text { R-IV }\end{array}$ & 25 & $\begin{array}{l}\text { I2 peptide } \\
\text { gpI00 } \\
\text { Tyrosinase } \\
\text { Mage-AI } \\
\text { Mage-A3 } \\
\text { Mage-AI0 } \\
\text { NY-ESO-I }\end{array}$ & $\begin{array}{l}\text { THP } \\
\text { Montanide } \\
\text { GM-CSF }\end{array}$ & $\begin{array}{l}\text { SC } \\
\text { and ID }\end{array}$ & $\begin{array}{l}\text { Med DFS and OS } \\
\text { not provided }\end{array}$ & $\begin{array}{l}\text { Greater immune } \\
\text { responses }\end{array}$ \\
\hline Slingluff et $\mathrm{al}^{73}$ & $\begin{array}{l}\text { R-IIB } \\
\text { R-III } \\
\text { R-IV }\end{array}$ & 41 & 12 peptide & $\begin{array}{l}\text { THP } \\
\text { Montanide } \\
\text { GM-CSF }\end{array}$ & $\begin{array}{l}\text { SC } \\
\text { and ID }\end{array}$ & $\begin{array}{l}\approx 75 \%-80 \% \\
3 \text {-year OS }\end{array}$ & $\begin{array}{l}78 \% \text { CD8 response } \\
93 \% \text { CD4 response }\end{array}$ \\
\hline Slingluff et $\mathrm{a}^{73}$ & $\begin{array}{l}\text { R-IIB } \\
\text { R-III } \\
\text { R-IV }\end{array}$ & 41 & 12 peptide & $\begin{array}{l}\text { THP } \\
\text { Montanide } \\
\text { GM-CSF } \\
\text { CTX }\end{array}$ & $\begin{array}{l}\text { SC } \\
\text { and ID }\end{array}$ & $\begin{array}{l}\approx 75 \%-80 \% \\
3 \text {-year OS }\end{array}$ & CTX had no effect \\
\hline Slingluff et $\mathrm{al}^{73}$ & $\begin{array}{l}\text { R-IIB } \\
\text { R-III } \\
\text { R-IV }\end{array}$ & 42 & $\begin{array}{l}12 \text { peptide }+ \\
6 \text { peptide }\end{array}$ & $\begin{array}{l}\text { THP } \\
\text { Montanide } \\
\text { GM-CSF }\end{array}$ & $\begin{array}{l}\text { SC } \\
\text { and ID }\end{array}$ & $\begin{array}{l}\approx 75 \%-80 \% \\
3 \text {-year OS }\end{array}$ & $\begin{array}{l}19 \% \text { CD8 response } \\
48 \% \text { CD4 }\end{array}$ \\
\hline Slingluff et $\mathrm{al}^{73}$ & $\begin{array}{l}\text { R-IIB } \\
\text { R-III } \\
\text { R-IV }\end{array}$ & 43 & $\begin{array}{l}12 \text { peptide }+ \\
6 \text { peptide }\end{array}$ & $\begin{array}{l}\text { THP } \\
\text { Montanide } \\
\text { GM-CSF } \\
\text { CTX }\end{array}$ & $\begin{array}{l}\text { SC } \\
\text { and ID }\end{array}$ & $\begin{array}{l}\approx 75 \%-80 \% \\
3 \text {-year OS }\end{array}$ & CTX had no effect \\
\hline Kruit et al ${ }^{143}$ & $\begin{array}{l}\text { U-III } \\
\text { Mla }\end{array}$ & 36 & Mage-A3 & ASI5 & IM & $\begin{array}{l}\text { 4/36 RR } 3 \text { CR } \\
\text { 3-month med PFS } \\
\text { 33-month med OS } \\
59 \% \text { 2-year OS }\end{array}$ & $\begin{array}{l}P \text {-values not } \\
\text { reported }\end{array}$ \\
\hline Kruit et al ${ }^{143}$ & $\begin{array}{l}\text { U-III } \\
\text { Mla }\end{array}$ & 36 & Mage-A3 & $\mathrm{ASO}_{2}$ & IM & $\begin{array}{l}\text { I/36 RR } \\
\text { 3-month med PFS } \\
\text { 20-month med OS } \\
\text { 37\% 2-year OS }\end{array}$ & \\
\hline Hodi et al ${ }^{15}$ & IV & 403 & gp 100 & Ipilimumab & SC & $\begin{array}{l}\text { 10.0-month OS } \\
5.7 \% \text { RR }\end{array}$ & $\begin{array}{l}P<0.00 I \text { vs } g \mathrm{PI} 00 \\
\text { alone }\end{array}$ \\
\hline Hodi et al ${ }^{15}$ & IV & 136 & gp 100 & Placebo & SC & $\begin{array}{l}\text { 6.4-month OS } \\
\text { I.4\% RR }\end{array}$ & \\
\hline Hodi et al ${ }^{15}$ & IV & 137 & Placebo & Ipilimumab & SC & $\begin{array}{l}\text { 10.1-month OS } \\
10.9 \% \text { RR }\end{array}$ & $\begin{array}{l}P=0.003 \text { vs gP } 100 \\
\text { alone }\end{array}$ \\
\hline
\end{tabular}


Table 7 (Continued)

\begin{tabular}{|c|c|c|c|c|c|c|c|}
\hline Author & Stage $^{213}$ & $\begin{array}{l}\text { Number } \\
\text { of patients }\end{array}$ & Antigen & $\begin{array}{l}\text { Adjuvant } \\
\text { or modifier }\end{array}$ & Route & Clinical efficacy & Other metrics \\
\hline $\begin{array}{l}\text { Schwartzentruber } \\
\text { et al }{ }^{144}\end{array}$ & IV & 85 & gp 100 & $\begin{array}{l}\text { Montanide } \\
\text { HD-IL-2 }\end{array}$ & SC & $\begin{array}{l}\text { I6\% RR } \\
\text { 3.9-month PFS } \\
\text { 25-month OS }\end{array}$ & $\begin{array}{l}P=0.03 \\
P=0.008 \\
P=0.06\end{array}$ \\
\hline $\begin{array}{l}\text { Schwartzentruber } \\
\text { et al }{ }^{144}\end{array}$ & IV & 93 & None & HD-IL-2 & & $\begin{array}{l}\text { 6\% RR } \\
\text { I.8-month PFS } \\
\text { II-month OS }\end{array}$ & \\
\hline
\end{tabular}

Abbreviations: CR, complete response; CTX, cyclophosphamide; DC, dendritic cells; DFS, disease-free survival; DTIC, dacarbazine; GM-CSF, granulocyte-macrophage colony-stimulating factor; HD, high-dose; ID, intradermal; IL, interleukin; IM, intramuscular; IV, intravenous; med, median; NSD, no significant difference; OS, overall survival; PBL, peripheral blood lymphocytes; PFS, progression-free survival; R, resected; RR, response rate; SC, subcutaneous; SLN, sentinel lymph node lymphocytes; THP, tetanus helper peptide; $U$, unresectable.

adjuvant (CpG 7909, MPL, and QS-21) in a Phase III trial (DERMA) in patients with stage IIIB or IIIC melanoma whose tumors express Mage-A3. It is estimated that $60 \%$ of melanomas in Europe express the antigen. ${ }^{143}$ Previous trials suggested some immune response to vaccination with Mage-3 but limited clinical activity (Table 6). ${ }^{131-133}$ A randomized Phase II trial suggested that Mage-3 might have greater activity when administered with AS15 rather than $\mathrm{ASO}_{\mathrm{B}}$ (Table 7). ${ }^{143}$

\section{Tumor-derived products}

Rather than focusing on specific antigens, many investigators have pursued tumor-derived products because of cancer heterogeneity, the extent of mutations in metastatic melanoma, and the inability to know every possible antigen for targeting.

\section{Preparations from whole allogeneic tumor}

One investigator prepared a lysate from a large amount of tumor harvested from a single patient. This lysate was injected into 129 patients with stage I melanoma and 61 with stage II disease and was associated with 5-year survival rates of $88 \%$ and $64 \%$, respectively. ${ }^{146}$ The subset of stage II patients appeared to have improved survival compared to published data. This approach is no longer desirable given the availability of allogeneic cell lines and the theoretical advantages of autologous tumor. The investigator himself abandoned this approach in favor of a lysate prepared from an allogeneic cell line, II-B-MEL-J, ${ }^{147}$ but a Phase II trial with this product was not completed.

\section{Allogeneic tumor cell lines}

Allogeneic tumor cell lines consist of proliferating, selfrenewing cancer cells that can be selected for expression of common MAA, although they cannot be expected to express all relevant MAA because of inter-patient tumor heterogeneity and unique patient-specific neoantigens. ${ }^{148}$ Allogeneic cell line products can be standardized and reproduced for clinical investigation, although they have to be continually monitored for genetic and phenotypic drift while in continuous culture. Several large randomized trials in melanoma patients have been conducted using whole tumor cells or lysates from allogeneic cell lines as antigen sources (Table 8). ${ }^{149-155}$ It should be noted that all of these trials were conducted in patients whose melanoma had been completely resected and had not recurred at the time of treatment. Two large trials used similar allogeneic viral oncolysates in patients with resected metastatic disease. ${ }^{150,151}$ The US trial, which enrolled patients with lymph node metastases, indicated stage II disease in one report ${ }^{150}$ but stage III subsequently. ${ }^{151}$ This trial was negative, but an Australian trial that enrolled patients with stage IIB disease and resected stage III showed trends favoring the vaccine. $^{152}$

Melacine $^{\mathrm{TM}}$ (Corixa Corporation, Seattle, WA, USA) is an allogeneic cell lysate mixed with DETOX that was no better than observation in stage IIB patients ${ }^{153}$ but was not clearly inferior to IFN- $\alpha$ in patients with resected stage III melanoma. ${ }^{154}$ Canvaxin $^{\mathrm{TM}}$ (CancerVax Corporation, Carlsbad, CA, USA), which consists of cells from two allogeneic cell lines admixed with BCG, was associated with a doubling of 5-year overall survival in patients with resected stage III melanoma and a tripling of 5-year survival in stage IV melanoma, compared to historical controls. ${ }^{156}$ In another retrospective comparison between patients who had undergone complete resection of metastatic melanoma lesions, 150 treated with Canvaxin ${ }^{\mathrm{TM}}$ had a 39\% 5-year survival compared to only $19 \%$ for 113 who did not receive the vaccine. ${ }^{157}$ However, results of two large double-blinded, placebo-controlled trials of Canvaxin ${ }^{\mathrm{TM}}$ in patients with resected stage III and IV disease were negative. The stage III trial was stopped for futility after a third analysis, and the stage IV trial was halted after a second interim analysis, at which time survival actually was better in the BCG placebo $\operatorname{arm}(P=0.04) .{ }^{155}$ These disappointing results with allogeneic 
Table 8 Randomized trials testing allogeneic vaccines and other agents

\begin{tabular}{|c|c|c|c|c|c|c|c|}
\hline Author & Stage $e^{213}$ & $\begin{array}{l}\text { Number } \\
\text { of patients }\end{array}$ & Antigen & $\begin{array}{l}\text { Adjuvant } \\
\text { or modifier }\end{array}$ & Route & Clinical efficacy & $\begin{array}{l}\text { Other } \\
\text { metrics }\end{array}$ \\
\hline Bystryn et al ${ }^{149}$ & R-III & 24 & $\begin{array}{l}\text { Allogeneic tumor } \\
\text { cell line shed antigen }\end{array}$ & Alum & ID & $\begin{array}{l}\text { 19-month med DFS } \\
67 \% 2 \text {-year OS } \\
\text { 3.8-year med OS }\end{array}$ & $\begin{array}{l}P=0.03 \\
\text { NSD }\end{array}$ \\
\hline Bystryn et al ${ }^{149}$ & R-III & 14 & None & Alum & ID & $\begin{array}{l}\text { 7-month med DFS } \\
61 \% 2 \text {-year OS } \\
2.7 \text {-year med OS }\end{array}$ & \\
\hline Wallack et $\mathrm{a}^{151}$ & R-III & 104 & $\begin{array}{l}\text { Allogeneic tumor } \\
\text { cell line lysate }\end{array}$ & Vaccinia & ID & $\begin{array}{l}42 \% 5 \text {-year DFS } \\
49 \% 5 \text {-year OS }\end{array}$ & $\begin{array}{l}P=0.61 \\
P=0.79\end{array}$ \\
\hline Wallack et al ${ }^{\mid 51}$ & R-III & 113 & None & Vaccinia & & $\begin{array}{l}40 \% 5 \text {-year DFS } \\
48 \% 5 \text {-year OS }\end{array}$ & \\
\hline Hersey et al ${ }^{152}$ & $\begin{array}{l}\text { IIB } \\
\text { R-III }\end{array}$ & 338 & $\begin{array}{l}\text { Allogeneic tumor } \\
\text { cell line lysate }\end{array}$ & Vaccinia & ID & $\begin{array}{l}\text { 6.9-year med PFS } \\
12.6 \text {-year med OS } \\
61 \% 5 \text {-year OS }\end{array}$ & $\begin{array}{l}P=0.17 \\
P=0.07\end{array}$ \\
\hline Hersey et al ${ }^{152}$ & $\begin{array}{l}\text { IIB } \\
\text { R-III }\end{array}$ & 335 & None & Vaccinia & & $\begin{array}{l}\text { 3.6-year med PFS } \\
7.3 \text {-year med OS } \\
55 \% 5 \text {-year OS }\end{array}$ & \\
\hline Sondak et al ${ }^{153}$ & IIB & 300 & $\begin{array}{l}\text { Allogeneic tumor } \\
\text { cell line lysate }\end{array}$ & DETOX & IM & $\begin{array}{l}66 \% 5 \text {-year DFS } \\
80 \% 5 \text {-year OS }\end{array}$ & $P=0.5 I$ \\
\hline Sondak et al ${ }^{153}$ & IIB & 300 & None & & & $\begin{array}{l}62 \% 5 \text {-year DFS } \\
80 \% 5 \text {-year OS }\end{array}$ & \\
\hline Mitchell et al ${ }^{154}$ & R-III & 294 & $\begin{array}{l}\text { Allogeneic tumor } \\
\text { cell line lysate }\end{array}$ & $\begin{array}{l}\text { DETOX } \\
\text { LD IFN- } \alpha\end{array}$ & IM & $\begin{array}{l}16 \% 5 \text {-year DFS } \\
62 \% 5 \text {-year OS }\end{array}$ & $\begin{array}{l}P=0.91 \\
P=0.91\end{array}$ \\
\hline Mitchell et al ${ }^{154}$ & R-III & 277 & None & HD IFN- $\alpha$ & & $\begin{array}{l}\text { I3\% 5-year DFS } \\
58 \% 5 \text {-year OS }\end{array}$ & \\
\hline Morton et al ${ }^{155}$ & R-III & $\approx 580$ & $\begin{array}{l}\text { Allogeneic tumor } \\
\text { cell line cells }\end{array}$ & BCG & ID & $\approx 63 \% 5$-year OS & NSD \\
\hline Morton et al $\left.\right|^{155}$ & R-III & $\approx 580$ & None & BCG & ID & $\approx 63 \% 5$-year OS & \\
\hline Morton et al ${ }^{155}$ & R-IV & $\approx 248$ & $\begin{array}{l}\text { Allogeneic tumor } \\
\text { cell line cells }\end{array}$ & BCG & ID & $\approx 42 \% 5$-year OS & \\
\hline Morton et al ${ }^{155}$ & R-IV & $\approx 248$ & None & BCG & ID & $\approx 42 \% 5$-year OS & $P=0.04$ \\
\hline
\end{tabular}

Abbreviations: alum, potassium aluminum sulfate; BCG, bacille Calmette-Guérin; DFS, disease-free survival; HD, high-dose; ID, intradermal; IFN, interferon; IM, intramuscular; LD, low-dose; med, median; NSD, no significant difference; OS, overall survival; PFS, progression-free survival.

cell lines remind us that no matter how encouraging immune response data and survival compared to historical controls may be, randomized trials are necessary to establish the benefit of vaccine therapies.

A polyvalent vaccine prepared from antigens shed into culture by one xenogenic and three allogeneic cell lines appeared safe and induced some immune-enhancing effects in 36 stage II and 19 stage III melanoma patients. ${ }^{158}$ In a 38-patient randomized trial, ID injections of antigens shed from an allogenic cell line and suspended in alum $(n=24)$ was associated with a survival that was no better than that observed in patients injected with alum plus albumin $(n=14)$, and the median survival was less than 4 years. ${ }^{149}$ The shed antigens have been characterized, ${ }^{110}$ and, in 2012, a randomized, double-blind, placebo-controlled trial in resected stage IIB, IIC, and III melanoma was initiated with a product called POL-103 AM $^{\mathrm{TM}}$ (Polynoma, Inc., San Diego, CA, USA) polyvalent melanoma vaccine.
In recent years, a few small trials have been conducted using autologous DC pulsed with antigens from allogeneic cell line lysates (Table 9)..$^{58,159-161}$ Antigen-specific immune responses were reported in all trials, but fewer than $10 \%$ of patients experienced objective responses and survival rates were not very encouraging. Given the generally disappointing results with allogeneic cell lines, it is not clear whether such products will be further developed.

\section{Preparations from whole autologous tumor}

Fresh or frozen autologous tumors have been used to prepare cell suspensions, lysates, or mechanically enriched tumor cell populations. Autologous tumors offer the theoretical advantage of being patient-specific in terms of tumor and histocompatibility antigens and are easier to prepare and more rapidly available than autologous tumor cell lines. However, this is only an option for patients who have surgically accessible 
Table 9 Trials of dendritic cells loaded with allogeneic antigens

\begin{tabular}{|c|c|c|c|c|c|c|c|}
\hline Author & Stage $^{213}$ & $\begin{array}{l}\text { Number } \\
\text { of patients }\end{array}$ & Antigen & $\begin{array}{l}\text { Adjuvant } \\
\text { or modifier }\end{array}$ & Route & Clinical efficacy & Other metrics \\
\hline Salcedo et al ${ }^{159}$ & $\begin{array}{l}\text { U-III } \\
\text { IV }\end{array}$ & 15 & $\begin{array}{l}\text { Allogeneic tumor } \\
\text { cell line lysate }\end{array}$ & $\begin{array}{l}\text { Hepatitis B protein } \\
\text { and/or tetanus } \\
\text { toxoid }\end{array}$ & $\begin{array}{l}\text { SC } \\
\text { ID } \\
\text { IN }\end{array}$ & I/I5 RR & $\begin{array}{l}\text { Antigen-specific } \\
\text { immune responses }\end{array}$ \\
\hline Palucka et al ${ }^{58}$ & IV & 20 & $\begin{array}{l}\text { Allogeneic tumor } \\
\text { cell line lysate }\end{array}$ & DC & SC & $\begin{array}{l}\text { 2/20 RR } \\
22 \text {-month med OS }\end{array}$ & $\begin{array}{l}3 / 13 \text { antigen-specific } \\
\text { immune response }\end{array}$ \\
\hline Lopez et al ${ }^{160}$ & IV & 43 & $\begin{array}{l}\text { Allogeneic tumor } \\
\text { cell line lysate }\end{array}$ & $\begin{array}{l}\text { DC } \\
\text { Alum or KLH }\end{array}$ & $\begin{array}{l}\text { ID or } \\
\text { SC }\end{array}$ & $\begin{array}{l}\text { 15-month med OS } \\
12 \% 5 \text {-year OS }\end{array}$ & $\begin{array}{l}\text { 21/39 DTH-T } \\
\text { response }\end{array}$ \\
\hline Ribas et al $\left.\right|^{161}$ & $\begin{array}{l}\text { U-III } \\
\text { IV-MIb }\end{array}$ & 33 & $\begin{array}{l}\text { Allogeneic tumor } \\
\text { cell line lysate }\end{array}$ & DC & $\begin{array}{l}\text { ID } \\
\text { and SC }\end{array}$ & $3 / 33 R R, I C R$ & $\begin{array}{l}26 / 29 \text { antigen- } \\
\text { specific responses }\end{array}$ \\
\hline
\end{tabular}

Abbreviations: alum, potassium aluminum sulfate; CR, complete response; DC, dendritic cells; DTH-T, delayed-type hypersensitivity reaction to tumor cells; ID, intradermal; IN, intranodal; KLH, keyhole limpet hemocyanin; med, median; OS, overall survival; RR, response rate; SC, subcutaneous; U, unresected.

tumors large enough to contain the desired number of cells for vaccine manufacturing. Furthermore, such vaccines often include variable numbers of immune cells and stromal cells in addition to malignant cells. Any tumor that is greater than a few millimeters in size mostly consists of more differentiated tumor cells rather than self-renewing tumor cells that may be a more critical target for complete eradication of tumor. Challenges that this approach shares with autologous tumor cell lines include the need to manufacture a specific product for each patient and the inter-patient variation in final treatment products. Trials utilizing cells from autologous tumor masses are summarized in Table $10 .{ }^{91,134,138,162-172}$ In patients with measurable disease, the response rate was 15\% (23/149 vs $12 / 82$ ) whether the autologous tumor cell products were loaded onto $\mathrm{DC}^{91,134,138,167-169}$ or not, ${ }^{162,163,166}$ but the response rate was only $5 \%(2 / 37)$ for the dendritoma products. ${ }^{170-172}$ Long-term survival data were limited.

\section{Autologous tumor cell suspensions}

The process required for this approach is exemplified in a trial in which eligible patients had to have more than $5 \mathrm{~g}$ of nonnecrotic tumor resected, from which aliquots of cells were prepared and cryopreserved. ${ }^{166}$ At the time of each treatment, an aliquot of frozen cells was thawed, washed, exposed to ultraviolet light, placed in cell culture for 24 hours, washed, suspended in phosphate-buffered saline, then mixed with DETOX for ID injection. This process was repeated every 2 weeks for six doses and then every 4 to 6 weeks.

Several other trials using autologous tumor were conducted in the pre-DC era. ${ }^{162-165}$ The approach included enzyme-digested cell suspensions of autologous tumor that were cryopreserved and subsequently thawed, washed, irradiated, suspended in a saline solution, and injected with BCG as an adjuvant. Dinitrophenol was later conjugated to tumor cells as a hapten, and patients were pretreated with low doses of cyclophosphamide to suppress T-cells. Each injection consisted of 10 to 25 million viable tumor cells. Over the years, objective tumor responses were reported for 11/83 stage IV patients, stage III patients had a 5-year survival rate of $44 \%$, and patients who had a delayed-type hypersensitivity response had twice the 5-year survival rate as patients who did not (59\% vs $29 \%, P<0.001) .{ }^{165}$ Such correlations are typical in vaccine trials, but such immune reactions may just be epiphenomena of immune competence rather than proof of an immune-induced benefit. Efforts were made to commercialize this product as M-Vax ${ }^{\mathrm{TM}}$ (AVAX Technologies, Philadelphia, PA, USA $),{ }^{173}$ but Phase III trials were never completed because of regulatory and financial hurdles. ${ }^{174}$

\section{DC pulsed with autologous tumor lysates}

More recent trials have focused on loading antigens from irradiated autologous tumor lysates onto autologous DC. ${ }^{91,134,138,167-169}$ Tumor size is not as critical for this approach because the final product is DC rather than tumor cells. Response rates in stage IV patients have ranged from $0 \%$ to $35 \%$, even with what appear to be identical approaches. ${ }^{168,169}$ The few complete responses reported have been durable, with responders surviving for several months to over a year.

\section{Autologous DC/tumor cell hybridomas}

Another approach with autologous tumor and DC is the creation of hybridomas of autologous tumor cells and autologous DC, which have also been termed dendritomas. ${ }^{175,176}$ The hybridomas have been created by electrofusion and polyethylene glycol methods. Small trials of such products have demonstrated some immune-mediated effects, but rarely tumor responses. ${ }^{170-172}$ 
Table 10 Clinical trials utilizing autologous tumor samples in the vaccines

\begin{tabular}{|c|c|c|c|c|c|c|c|}
\hline Author & Stage $e^{213}$ & $\begin{array}{l}\text { Number } \\
\text { of patients }\end{array}$ & Antigen & $\begin{array}{l}\text { Adjuvant } \\
\text { or modifier }\end{array}$ & Route & Clinical efficacy & Other metrics \\
\hline Laucius et $\mathrm{a}^{162}$ & IV & 18 & Autologous tumor & $\mathrm{BCG}$ & ID & 4/I8 RR & \\
\hline \multirow[t]{2}{*}{ Berd et al ${ }^{163}$} & R-III & 64 & Autologous tumor & BCG & ID & $6 / 40 \mathrm{RR}$ & 20/62 DTH-T \\
\hline & IV & & & CTX & & & \\
\hline \multirow[t]{2}{*}{ Berd et al ${ }^{164}$} & R-III & 62 & Autologous tumor & DNP & ID & $58 \%$ 5-year OS & 2I/24 DTH-T \\
\hline & & & & $\mathrm{BCG}$ & & & \\
\hline \multirow[t]{3}{*}{ Berd et al ${ }^{165}$} & R-III & 214 & Autologous tumor & DNP & ID & $33 \% 5$-year DFS & 47\% DTH-T \\
\hline & $2.5 \mathrm{~cm}$ & & & $\mathrm{BCG}$ & & $44 \%$ 5-year OS & \\
\hline & tumor & & & CTX & & & \\
\hline \multirow[t]{3}{*}{ Eton et al ${ }^{166}$} & R-IV & 42 & Autologous tumor & DETOX & ID & $2 / 24 R R$ & 8/35 DTH-T \\
\hline & U-IV & & & & & 16-month med OS & \\
\hline & $5 \mathrm{~g}$ tumor & & & & & & \\
\hline O'Rourke et al ${ }^{167}$ & IV & 17 & Autologous tumor & $\mathrm{DC}$ & ID & 6/I7 RR, 3 CR & \\
\hline O'Rourke et al ${ }^{91}$ & IV & 46 & Autologous tumor & DC & ID & 6/46 RR, $3 \mathrm{CR}$ & \\
\hline \multirow[t]{3}{*}{ Ridolfi et al $\left.\right|^{168}$} & IV & 27 & Autologous tumor & $D C$ & SC or ID & $8 / 27 \mathrm{RR}, 2 \mathrm{CR}$ & DTH-V positive \\
\hline & & & & KLH & & 16-month med OS & in $15 / 15$ non-PD \\
\hline & & & & LD IL-2 & & & \\
\hline \multirow[t]{3}{*}{ Redman et $\mathrm{al}^{169}$} & IV & 24 & Autologous tumor & DC & ID & 0/24 RR & $3 / 14$ converted \\
\hline & & & & KLH & & & DTH-T \\
\hline & & & & LD or HD IL-2 & & & \\
\hline \multirow[t]{2}{*}{ Hersey et al ${ }^{134}$} & IV & 19 & Autologous tumor & Immature DC & IN & $3 / 19 R R$ & $5 / 15$ converted \\
\hline & & & & $\mathrm{KLH}$ & & & DTH-T \\
\hline \multirow[t]{2}{*}{ Hersey et $\mathrm{al}^{138}$} & IV & 16 & Autologous tumor & Mature DC & IN & $0 / 16 R R$ & \\
\hline & & & & $\mathrm{KLH} \pm \mathrm{LD}$ IL-2 & & I8-month med OS & \\
\hline Krause et $\mathrm{al}^{170}$ & IV & 17 & Autologous tumor & DC dendritoma & SC & $1 / 17$ & \\
\hline Haenssle et $\mathrm{al}^{171}$ & IV & 11 & Autologous tumor & DC dendritoma & ID or SC & $0 / 11$ & \\
\hline Wei et al $\left.\right|^{172}$ & IV & 9 & Autologous tumor & DC dendritoma & SC & $1 / 9$ & \\
\hline
\end{tabular}

Abbreviations: BCG, bacille Calmette-Guérin; CR, complete response; CTX, cyclophosphamide; DC, dendritic cells; DFS, disease-free survival; DNP, dinitrophenol; DTH-T, delayed-type hypersensitivity reaction to tumor cells; DTH-V, delayed type hypersensitivity reaction to vaccine; HD, high-dose; ID, intradermal; IL, interleukin; IN, intranodal; KLH, keyhole limpet hemocyanin; LD, low-dose; med, median; OS, overall survival; PD, progressive disease; R, resected; RR, response rate; SC, subcutaneous.

\section{Heat shock proteins}

Heat shock proteins carry or "chaperone" tumor antigens in the context of HLA-class I antigens, and can be isolated from other cells present in whole autologous tumor. The product referred to as HSPPC-96 (vitespen) consists of heat shock proteins associated with the gp96 antigen. ${ }^{177}$ Although whole tumor cells are not involved in this approach, sufficiently large tumors are needed to obtain the quantity of HSPPC-96 needed for a reproducible product. Reported trials with this approach are summarized in Table 11. ${ }^{178,179}$ The Phase III trial was conducted using a 2:1 randomization in stage IV melanoma patients to compare vitespen to a control group in which physicians were to choose among complete tumor resection, dacarbazine, temozolomide, or IL-2 for treatment. ${ }^{179}$ Unfortunately, a satisfactory vitespen product could only be prepared for $141 / 215$ patients (66\%), and only 133 started therapy, a median of 41 days after randomization. Furthermore, only 86/117 patients randomized to the control arm remained in the study. This illustrates the challenges of an intent-to-treat design for patient-specific products. There

Table I I Heat shock protein vaccine derived from autologous tumor

\begin{tabular}{|c|c|c|c|c|c|c|c|}
\hline Author & Stage $^{213}$ & $\begin{array}{l}\text { Number } \\
\text { of patients }\end{array}$ & Antigen & $\begin{array}{l}\text { Adjuvant } \\
\text { or modifier }\end{array}$ & Route & Clinical efficacy & Other metrics \\
\hline Belli et al ${ }^{178}$ & IV & 42 & $\begin{array}{l}\text { Autologous } \\
\text { gp } 96\end{array}$ & $\begin{array}{l}\text { Heat shock } \\
\text { protein }\end{array}$ & SC or ID & 2/28 RR, 2 CR & $\begin{array}{l}\text { Increased antigen-specific } \\
\text { immune response }\end{array}$ \\
\hline Testori et al ${ }^{179}$ & IV & $\begin{array}{l}215 \\
133\end{array}$ & $\begin{array}{l}\text { Autologous } \\
\text { gp96 }\end{array}$ & $\begin{array}{l}\text { Heat shock } \\
\text { protein }\end{array}$ & SC & $<20 \% 3$-year OS & $\begin{array}{l}P=0.31 \text { by ITT analysis } \\
P=0.25 \text { by actual treatment }\end{array}$ \\
\hline Testori et al ${ }^{179}$ & IV & $\begin{array}{l}107 \\
86\end{array}$ & None & $\begin{array}{l}\text { IL-2 or DTIC } \\
\text { or TMZ }\end{array}$ & & $<20 \% 3$-year OS & \\
\hline
\end{tabular}

Abbreviations: CR, complete response; DTIC, dacarbazine; DTH-T, delayed-type hypersensitivity reaction to tumor cells; ID, intradermal; IL, interleukin; ITT, intent-totreat; OS, overall survival; RR, response rate; SC, subcutaneous; TMZ, temozolomide. 
was no difference in progression-free or overall survival by the intent-to-treat analysis from the date of randomization, nor for patients who were actually treated per the protocol.

\section{Autologous tumor cell lines}

Theoretically, self-renewing, continuously proliferating autologous tumor cells may be the best antigen source for vaccine therapy. ${ }^{180,181}$ Pure autologous tumor cells maximize the potential to present any and all MAA, including unique neoantigens, and assure lack of exposure to irrelevant allogeneic antigens that might actually diminish the immune response to important MAA. Autologous tumor cell lines can be a renewable source of tumor cells and tumor antigen for correlative laboratory experiments. The abilities to self-renew and proliferate are prerequisites for tumor stem cells and early tumor progenitor cells. Melanoma tumor stem cells have been characterized by phenotype and metastatic potential. ${ }^{182-188}$ Such cells are characterized by inherent resistance to cytotoxic therapy and protection from the host immune system, and appear to be responsible for tumor recurrence at new and previous sites of disease despite other anti-melanoma therapies. Even though targeting a small subpopulation of tumor stem cells would not be expected to produce a rapid or dramatic effect on large sites of metastatic melanoma, this approach may be needed to prevent recurrence of melanoma. Animal experiments have shown that small tumors can be completely eradicated by targeting a small subset of cells rather than trying to target antigens expressed on the highest percentage of tumor cells. ${ }^{189}$ Long-term clinical benefit in patients treated with vaccines targeting such self-renewing cells may be due to an immune response against melanoma stem cells. ${ }^{190}$ In patients with extensive metastatic disease, other therapies would be needed to rapidly reduce the tumor burden of more differentiated melanoma cells while the autologous cell line vaccine was being prepared.

All surgically removed tissue is consumed during the diagnostic evaluation of primary melanomas and sentinel lymph nodes; therefore, vaccines derived from autologous tumor cell lines are an option only for patients who have gross metastatic disease. Thus, this approach cannot be used to prevent melanoma or as an adjuvant treatment to prevent recurrence of deep primary melanoma or patients with microscopic stage III nodal metastases. However, regional recurrences and distant melanoma metastases often occur in sites that are readily accessible to biopsy and/or surgical excision, which provides an opportunity to obtain fresh tissue from which to establish short-term cell cultures. Challenges related to this approach include having to establish a cell line for each patient, the inability to establish a cell line for every patient, and the time needed to establish the autologous tumor cell line and expand it to sufficient numbers for therapy. Better media for growing tumor stem cells would make this approach more attractive.

The labor intensiveness and complexity of establishing autologous cell lines has discouraged most investigators and companies from pursing such an approach, although it is technically feasible. ${ }^{180,191,192}$ Clinical trials in which short-term autologous tumor cell lines were used as antigen sources for patient-specific vaccines have yielded encouraging long-term survival results (Table 12). ${ }^{62,193,194}$ Two products have been tested: irradiated tumor cells and DC loaded with antigens from the irradiated cells. Comparison of successive trials and a small randomized Phase II trial suggest that survival is increased in patients receiving the DC vaccine. ${ }^{193,194}$ The survival curves in each arm of the randomized trial were similar to those generated in the two previous single-arm

Table 12 Vaccines using antigens from autologous tumor cell lines

\begin{tabular}{|c|c|c|c|c|c|c|c|}
\hline Author & Stage $^{213}$ & $\begin{array}{l}\text { Number } \\
\text { of patients }\end{array}$ & Antigen & $\begin{array}{l}\text { Adjuvant } \\
\text { or modifier }\end{array}$ & Route & Clinical efficacy & Other metrics \\
\hline Dillman et $a^{62}$ & $\begin{array}{l}23-I I I \\
5 I-I V\end{array}$ & 74 & $\begin{array}{l}\text { Autologous tumor } \\
\text { cell line }\end{array}$ & $\begin{array}{l}\text { GM-CSF and/or } \\
\text { IFN- } \gamma \text {, IFN- } \alpha \text {, } \\
\text { BCG, none }\end{array}$ & SC & $\begin{array}{l}\text { 3/38 RR } \\
20 \text {-month med OS } \\
31 \% \text { 2-year OS } \\
29 \% 5 \text {-year OS }\end{array}$ & $\begin{array}{l}\text { I0/43 } \\
\text { DTH-T conversion }\end{array}$ \\
\hline Dillman et al ${ }^{193}$ & $\begin{array}{l}\text { I4-III } \\
40-I V\end{array}$ & 54 & $\begin{array}{l}\text { Autologous tumor } \\
\text { cell line }\end{array}$ & $\begin{array}{l}\text { DC } \\
\text { GM-CSF }\end{array}$ & SC & $\begin{array}{l}\text { 0/I5 RR } \\
\text { 5-year med OS } \\
73 \% \text { 2-year OS } \\
\text { 54\% 5-year OS }\end{array}$ & $\begin{array}{l}\text { I3/53 } \\
\text { DTH-T conversion }\end{array}$ \\
\hline Dillman et al ${ }^{194}$ & $\begin{array}{l}6-111 \\
I 8-I V\end{array}$ & 24 & $\begin{array}{l}\text { Autologous tumor } \\
\text { cell line }\end{array}$ & GM-CSF & SC & $31 \% 2$-year OS & \\
\hline Dillman et al ${ }^{194}$ & $\begin{array}{l}3-I I I \\
\text { I5-IV }\end{array}$ & 18 & $\begin{array}{l}\text { Autologous tumor } \\
\text { cell line }\end{array}$ & $\begin{array}{l}\text { DC } \\
\text { GM-CSF }\end{array}$ & SC & $\begin{array}{l}72 \% \text { 2-year OS } \\
\text { I CR }\end{array}$ & $P=0.007$ \\
\hline
\end{tabular}

Abbreviations: BCG, bacille Calmette-Guérin; CR, complete response; DC, dendritic cells; DTH-T, delayed-type hypersensitivity reaction to tumor cells; GM-CSF, granulocyte-macrophage colony-stimulating factor; IFN, interferon; med, median; OS, overall survival; R, resected; RR, response rate; SC, subcutaneous. 
trials. Long-term progression-free survival was documented for many patients who, despite various therapies, previously had been progression-free for no more than a few weeks to months. ${ }^{190}$ One patient treated with the DC vaccine, who was progression-free for no more than a few weeks during her first year after being diagnosed with metastases to the cervical spine, had complete remission of SC metastases, which persisted for at least 5 years. ${ }^{195}$ Cell lines were established for more than half of patients who submitted tumor samples, and the median time needed to establish and expand cell lines was about 4 months. In all of these trials, vaccine doses were injected weekly for 3 weeks, then monthly for up to 5 additional months. The major criteria for treatment were the successful establishment of the autologous tumor cell line and the managing oncologist referring the patient for vaccine therapy. A multivariate analysis suggested that the most important laboratory predictor of survival was resistance of the tumor cells to IFN- $\gamma$, a feature that is important for survival of tumor stem cells. ${ }^{196,197}$ A confirmatory doubleblind, randomized Phase III trial of this autologous dendritic cell-tumor cell product, melapuldencel-T, has been submitted to FDA, using stem cell media that decrease the time needed to establish a tumor cell line and increase the probability of establishing a cell line.

Cells from autologous melanoma cell lines have been molecularly engineered to secrete adjuvants. In a Phase I dose escalation trial, 20 patients were safely treated with autologous melanoma cells that had been gene-modified to secrete GM-CSF. ${ }^{198}$ At least two Phase I trials have been performed utilizing cells from autologous melanoma cell lines that had been gene-modified to secrete GM-CSF. Toxicity was insignificant in both trials and clinical responses were reported for $1 / 30$ patients ${ }^{199}$ and $2 / 34$ patients. ${ }^{200}$ No further studies with these products have been reported.

\section{Injections into existing tumors}

An approach that obviates the need to administer an antigen product involves the injection of immune-stimulating substances into existing tumor lesions. For many years, investigators have injected various immune-stimulating substances, such as BCG and various cytokines, into tumor masses, not only for a local tumor response and regression of SC and in-transit metastases, but also in an effort to induce or enhance the endogenous antitumor immune response. ${ }^{201} \mathrm{~A}$ variety of agents have been injected for this purpose, including BCG, ${ }^{202} \mathrm{IFN}-\alpha,{ }^{203} \mathrm{IFN}-\gamma,{ }^{204} \mathrm{IL}-2,{ }^{205}$ and GM-CSF. ${ }^{206}$ Local antitumor effects have been reported for many of these patients, but most of this experience has been in soft tissue disease. Unfortunately, the desired effects of distant tumor control and increased survival, an indication of induction of systemic anticancer immune effects, has not been demonstrated.

Fusion products for IT injection have been designed, and two have proceeded to Phase III trials (Table 13). The first, Allovectin-7 ${ }^{\mathrm{TM}}$ (Vical, Inc., San Diego, CA, USA) (velimogene aliplasmid), is a DNA plasmid-liposome product that contains genes for an allogeneic HLA-B7 class I histocompatibility antigen and beta2-microglobulin. ${ }^{207-209}$ The duration of disease control was disappointing, even though patients with an elevated lactic dehydrogenase

Table 13 Injections into autologous tumor

\begin{tabular}{|c|c|c|c|c|c|c|c|}
\hline Author & Stage $^{213}$ & $\begin{array}{l}\text { Number } \\
\text { of patients }\end{array}$ & Antigen & $\begin{array}{l}\text { Adjuvant } \\
\text { or modifier }\end{array}$ & Route & Clinical efficacy & Other metrics \\
\hline \multirow[t]{2}{*}{ Stopeck et al ${ }^{208}$} & U-III & 52 & Autologous tumor & HLA-B7 & IT & $2 / 5 I R R$ & $4 / 51$ regression \\
\hline & IV & & & $\beta 2 \mathrm{M}$ liposome & & & of injected lesions \\
\hline \multirow{2}{*}{ Bedikian et a ${ }^{209}$} & U-III & 133 & Autologous tumor & HLA-B7 & IT & I5/I27 RR & Excluded patients \\
\hline & IV & & & $\beta 2 M$ liposome & & I.6-month med PFS & with $\uparrow \mathrm{LDH}$ \\
\hline \multirow[t]{3}{*}{ Senzer et $\mathrm{a}^{210}$} & U-IIIB & 50 & Autologous tumor & Herpes simplex- & IT or IN & $26 \% \mathrm{RR}, 8 \mathrm{CR}$ & \\
\hline & U-IIIC & & & GM-CSF & & $50 \%$ I-year OS & \\
\hline & IV & & & & & & \\
\hline \multirow[t]{4}{*}{ Kaufman et $\mathrm{a}^{212}$} & U-IIIB & $\approx 290$ & Autologous tumor & Herpes simplex- & IT & $26 \% R R$ & $P<0.001$ \\
\hline & U-IIIC & & & GM-CSF & & $16 \%$ RR $>6$-month & $P<0.001$ \\
\hline & U-IV & & & & & 8-month med PFS & $P<0.001$ \\
\hline & & & & & & 23-month med OS & $P=0.07$ \\
\hline \multirow[t]{4}{*}{ Kaufman et a $\left.\right|^{212}$} & U-IIIB & $\approx 145$ & & GM-CSF & SC & $6 \% R R$ & \\
\hline & U-IIIC & & & & & $2 \% \mathrm{RR}>6$-month & \\
\hline & U-IV & & & & & 3-month med PFS & \\
\hline & & & & & & 19-month med OS & \\
\hline
\end{tabular}

Abbreviations: $\beta 2 \mathrm{M}$, beta-2 microglobulin; CR, complete response; GM-CSF, granulocyte-macrophage colony-stimulating factor; HLA, human lymphocyte antigen; IN, intranodal; IT, intratumoral; LDH, lactic dehydrogenase; med, median; OS, overall survival; PFS, progression-free survival; RR, response rate; SC, subcutaneous; $\mathrm{U}$, unresectable. 
were excluded. The second, OncoVEX ${ }^{\mathrm{TM}}$ (Amgen, Inc., Thousand Oaks, CA, USA) GM-CSF (T-Vec, talimogene laherparepvec) consists of an attenuated oncolytic herpes simplex virus transfected with a GM-CSF gene, which is believed to replicate preferentially in tumor cells. ${ }^{210} \mathrm{Six}$ responses were documented after initial disease progression, and some responses were not evident for many months after discontinuation of treatment. Importantly, tumor regressions were documented both for injected lesions and lesions that had not been injected. ${ }^{211}$ The results for a randomized Phase III trial (OPTIM) appear to be positive, ${ }^{212}$ although the control arm was SC GM-CSF rather than IT GM-CSF, which would have been a more appropriate control, and median overall survival was less than 2 years.

\section{Summary}

There are numerous strategies for immunotherapy with MAA, but, to date, no anti-melanoma vaccine has received regulatory approval. In clinical trials, vaccines have been associated with minimal toxicity while inducing or enhancing immune responses against specific MAA, but these effects do not necessarily translate into clinical benefit. It appears that various adjuvants and cytokine biological response modifiers can enhance immune responses to MAA, but there are insufficient comparative data to determine an optimal strategy with regard to incorporating these non-MAA vaccine components. However, the one FDA-approved therapeutic cancer vaccine, sipuleucel-T for prostate cancer, includes GM-CSF and antigen presentation by DC. Randomized trials using MAA from allogeneic melanoma cell lines have failed to provide a survival benefit for patients with resected disease. ${ }^{149,151-155}$ In patients with measurable disease, the $15 \%$ response rate for autologous tumor cell vaccines ${ }^{62,91,134,138,162,163,166-169,193}$ appears higher $(38 / 284$ vs $20 / 271, P=0.021)$ than the $7 \%$ response rate for peptide vaccines..$^{94,125,126,130-134,136-139}$ Although there is no apparent difference in response rates for DC-based autologous tumor vaccines ${ }^{91,134,138,167-169}$ compared to autologous tumor, ${ }^{162,163,166}$ a recent randomized trial showed a survival advantage for patients treated with GM-CSF/DC-tumor cell vaccines compared to GM-CSF/autologous tumor cell vaccines. ${ }^{194}$ Thus, it appears that autologous approaches will be required to optimize therapeutic benefit by inducing and/or enhancing patient-specific polyvalent immune responses. Experience with immunotherapeutics has shown that the most important endpoints for clinical trials are not tumor response rates or progression-free survival, but rather long-term overall survival, which can only be established by randomized, controlled, prospective trials. ${ }^{15,70}$ Therapeutic vaccines are expected to enhance, rather than replace, other anti-melanoma immune therapies. Despite the failure of gp100 to add benefit to ipilimumab, ${ }^{15}$ there is reason to believe that effective vaccines will work synergistically with monoclonal antibodies that interfere with T-cell checkpoint molecules.

\section{Disclosure}

The author and/or immediate family have stock in several companies whose products are mentioned in the article (Bristol-Myers Squibb, GlaxoSmithKline, Merck) and stock options in the company California Stem Cell, Inc., which is pursuing a patient-specific melanoma tumor cell vaccine product, having acquired the rights to the clinical data and intellectual property through an agreement with Hoag Hospital. The author also has received honoraria through speakers bureaus sponsored by Prometheus and Genentech. The author reports no other conflicts of interest in this work.

\section{References}

1. Delves PJ, Roitt IM. The immune system. First of two parts. $N$ Engl J Med. 2000;343(1):37-49.

2. Delves PJ, Roitt IM. The immune system. Second of two parts. N Engl J Med. 2000;343(2):108-117.

3. Finn OJ. Cancer immunology. N Engl J Med. 2008(25);358: 2704-2715.

4. Schreiber RD, Old IJ, Smyth MJ. Cancer immunoediting: integrating immunity's role in cancer suppression and promotion. Science. 2011;331(6024):1565-1570.

5. Dillman RO. Cancer immunotherapy. Cancer Biother Radiopharm. 2011;26(1):1-64.

6. Bulkley G, Cohen MH, Banks PM, Char DH, Ketcham AS. Longterm spontaneous regression of malignant melanoma with visceral metastases. Report of a case with immunologic profile. Cancer. 1975;36(2):485-494.

7. Kalialis LV, Drzewiecki KT, Klwer H. Spontaneous regression of metastases from melanoma: review of the literature. Melanoma Res. 2009; 19(5):275-282.

8. Clemente CG, Mihm MC Jr, Bufalino R, Zurrida S, Collini P, Cascinelli N. Prognostic value of tumor infiltrating lymphocytes in the vertical growth phase of primary cutaneous melanoma. Cancer. 1996;77(7): 1303-1310.

9. Mihm MC Jr, Clemente CG, Cascinelli N. Tumor infiltrating lymphocytes in lymph node melanoma metastases: a histopathologic prognostic indicator and an expression of local immune response. Lab Invest. 1996;74(1):43-47.

10. Holmes EC, Eilber FR, Morton DL. Immunotherapy of malignancy in humans. Current status. JAMA. 1975;232(10):1052-1055.

11. Stewart JH 4th, Levine EA. Role of bacillus Calmette-Guerin in the treatment of advanced melanoma. Expert Rev Anticancer Ther. 2011;11(11):1671-1676.

12. Kirkwood JM, Strawderman MH, Ernstoff MS, Smith TJ, Borden EC, Blum RH. Interferon alfa-2b adjuvant therapy of high-risk resected cutaneous melanoma: the Eastern Cooperative Oncology Group Trial EST 1684. J Clin Oncol. 1996;14(1):7-17.

13. Eggermont AM, Suciu S, Testori A, et al. Long-term results of the randomized phase III trial EORTC 18991 of adjuvant therapy with pegylated interferon alfa- $2 \mathrm{~b}$ versus observation in resected stage III melanoma. J Clin Oncol. 2012;30(31):3810-3818. 
14. Atkins MB, Lotze MT, Dutcher JP, et al. High-dose recombinant interleukin 2 therapy for patients with metastatic melanoma: analysis of 270 patients treated between 1985 and 1993. J Clin Oncol. 1999; 17(7):2105-2116.

15. Hodi FS, O’Day SJ, McDermott DF, et al. Improved survival with ipilimumab in patients with metastatic melanoma. $N$ Engl J Med. 2010;363(8):711-723.

16. Topolian SL, Hodi FS, Brahmer JR, et al. Safety, activity, and immune correlates of anti-PD-1 antibody in cancer. $N$ Engl J Med. 2012;366(26):2443-2454.

17. Hamid O, Robert C, Daud A, et al. Safety and tumor responses with lambrolizumab (Anti-PD-1) in melanoma. $N$ Engl $\mathrm{J}$ Med 2013;369(2):134-144.

18. Brahmer JR, Tykodi SS, Chow LQ, et al. Safety and activity of antiPD-L1 antibody in patients with advanced cancer. $N$ Engl $J$ Med. 2012;366(26):2455-2465.

19. Gogas H, Ioannovich J, Dafni U, et al. Prognostic significance of autoimmunity during treatment of melanoma with interferon. $N$ Engl J Med. 2006;354(7):709-718.

20. Phan GQ, Attia P, Steinberg SM, White DE, Rosenberg SA. Factors associated with response to high-dose interleukin-2 in patients with metastatic melanoma. J Clin Oncol. 2001;19(15):3477-3482.

21. Weber J. Ipilimumab: controversies in its development, utility and autoimmune adverse events. Cancer Immunol Immunother. 2009 58(5):823-830.

22. Kirkwood JM, Bender C, Agarwala S, et al. Mechanisms and management of toxicities associated with high-dose interferon alfa-2b therapy. J Clin Oncol. 2002;20(17):3703-3718.

23. Dillman RO. The clinical experience with interleukin-2 in cancer therapy. Cancer Biother. 1994;9(3):183-209.

24. Schwartz RN, Stover L, Dutcher J. Managing toxicities of high-dose interleukin-2. Oncology (Williston Park). 2002;16(11 Suppl 13): 11-20.

25. Rosenberg SA, Lotze MT, Muul LM, et al. A progress report on the treatment of 157 patients with advanced cancer using lymphokine-activated killer cells and interleukin-2 or high-dose interleukin-2 alone. $N$ Engl J Med. 1987;316(15):889-897.

26. West WH, Tauer KW, Yannelli JR, et al. Constant infusion recombinant interleukin-2 in adoptive immunotherapy of advanced cancer. $N$ Engl J Med. 1987;316(15):898-905.

27. Dutcher JP, Gaynor ER, Fisher RI, et al. A phase II study of high-dose continuous infusion interleukin-2 with lymphokine-activated killer cells in patients with metastatic melanoma. J Clin Oncol. 1991;9(4):641-648.

28. Dillman RO, Oldham RK, Tauer KW, et al. Continuous interleukin-2 and lymphokine-activated killer cells for advanced cancer: a National Biotherapy Study Group trial. J Clin Oncol. 1991;9(7):1233-1340.

29. Rosenberg SA, Lotze MT, Yang JC, et al. Prospective randomized trial of high-dose interleukin-2 alone or in conjunction with lymphokineactivated killer cells for the treatment of patients with advanced cancer. J Natl Cancer Inst. 1993;85(8):622-632.

30. Rosenberg SA, Packard BS, Aebersold PM, et al. Use of tumorinfiltrating lymphocytes and interleukin-2 in the immunotherapy of patients with metastatic melanoma. A preliminary report. $N$ Engl J Med. 1988;319(25):1676-1680.

31. Dillman RO, Oldham RK, Barth NM, et al. Continuous interleukin-2 and tumor-infiltrating lymphocytes as treatment of advanced melanoma. A national biotherapy study group trial. Cancer. 1991;68(1):1-8.

32. Dudley ME, Wunderlich JR, Yang JC, et al. Adoptive cell transfer therapy following non-myeloablative but lymphodepleting chemotherapy for the treatment of patients with refractory metastatic melanoma J Clin Oncol. 2005;23(10):2346-2357.

33. Rosenberg SA, Yang JC, Sherry RM, et al. Durable complete responses in heavily pretreated patients with metastatic melanoma using T-cell transfer immuotherapy. Clin Cancer Res. 2011;17(13):4550-4557.

34. Dudley ME, Gross CA, Somerville RP, et al. Randomized selection design trial evaluating CD8+-enriched versus unselected tumor infiltrating lymphocytes for adoptive cell therapy for patients with melanoma. J Clin Oncol. 2013;31(17):152-159.
35. Schijns VE, Lavelle EC. Trends in vaccine adjuvants. Expert Rev Vaccines. 2011;10(4):539-550.

36. Aucouturier J, Dupuis L, Deville S, Ascarateil S, Ganne V. Montanide ISA 720 and 51: a new generation of water in oil emulsions as adjuvants for human vaccines. Expert Rev Vaccines. 2002;1(1):111-118.

37. Coley WB. The treatment of malignant tumors by repeated inoculations of erysipelas: with a report of ten original cases. Am J Med Sci. 1893;(105):487-511.

38. Bast RC Jr, Zbar B, Borsos T, Rapp HJ. BCG and cancer. $N$ Engl J Med. 1974;20(25)(Pt 1)290:1413-1420.

39. Bast RC Jr, Zbar B, Borsos T, Rapp HJ. BCG and cancer. $N$ Engl J Med. 1974;290(26)(Pt 2):1458-1469.

40. Vosika GJ. Clinical immunotherapy trials of bacterial components derived from Mycobacteria and Nocardia. J Biol Response Mod. $1983 ; 2(4): 321-342$

41. Lipton A, Harvey Ha, Lawrence B, et al. Corynebacterium parvum versus BCG adjuvant immunotherapy in human malignant melanoma. Cancer. 1983;51(1):57-60.

42. Chirigos MA, Saito T, Talmadge JE, Budzynski W, Gruys E. Cell regulatory and immunorestorative activity of picibanil (OK432). Cancer Detect Prev Suppl. 1987;(1):317-328.

43. Toso TF, Gill VJ, Hwu P, et al. Phase I study of the intravenous administration of attenuated Salmonella typhimurium to patients with metastatic melanoma. J Clin Oncol. 2002;20(1):142-152.

44. Adkins I, Holubova J, Kosova M, Sadikova L. Bacteria and their toxins tamed for immunotherapy. Curr Pharm Biotechnol. 2012;13(8): 1446-1473.

45. Schultz N, Oratz R, Chen D, Zeleniuch-Jacquotte A, Abeles G, Bystryn JC. Effect of DETOX as an adjuvant for melanoma vaccine. Vaccine. 1995;13(5):503-508.

46. Harris JR, Markl J. Keyhole limpet hemocyanin (KLH): a biomedical review. Micron. 1999;30(6):597-623.

47. Wallack MK, Steplewski Z, Koprowski H, et al. A new approach in specific, active immunotherapy. Cancer. 1977;39(2):560-564.

48. Moss B. Vaccinia virus: a tool for research and vaccine development. Science. 1991;252(5013):1662-1667.

49. Arlen PM, Gulley JL, Madan RA, Hodge JW, Schlom J. Preclinical and clinical studies of recombinant poxvirus vaccines for carcinoma therapy. Crit Rev Immunol. 2007;27(5):451-462.

50. Kim JW, Gulley JL. Poxviral vectors for cancer immunotherapy. Expert Opin Biol Ther. 2012;12(4):463-478.

51. Raquopathi G, Gardner JR, Livingston PO, Gin DY. Natural and synthetic saponin adjuvant QS-21 for vaccines against cancer. Expert Rev Vaccines. 2011;10(4):463-470.

52. Cluff CW. Monophosphoryl lipid A (MPL) as an adjuvant for anticancer vaccines: clinical results. Adv Exp Med Biol. 2010;667:111-123.

53. Parmiani G, Rivoltini L, Andeola G, Carrabba M. Cytokines in cancer therapy. Immunol Lett. 2000;74(1):41-44.

54. Dillman RO, Beutel LD, Barth NM, et al. Irradiated cells from autologous tumor cell lines as patient-specific vaccine therapy in 125 patients with metastatic cancer: induction delayed-type hypersensitivity to autologous tumor is associated with improved survival. Cancer Biother Radiopharm. 2002;17(1):51-66.

55. Disis ML, Bernhard H, Shiota FM, et al. Granulocyte-macrophage colony-stimulating factor: an effective adjuvant for protein and peptidebased vaccines. Blood. 1996;88(1):202-210.

56. Dranoff G. GM-CSF-based cancer vaccines. Immunol Rev. 2002; (188):147-154.

57. Luiten RM, Kueter EW, Mooi W, et al. Immunogenicity, including vitiligo, and feasibility of vaccinating with autologous GM-CSF-transduced tumor cells in melanoma patients. J Clin Oncol. 2005;23(35):8978-8991.

58. PaluckaAK, Ueno H, Connolly J, et al. Dendritic cells loaded with killed allogeneic melanoma cells can induce objective clinical responses and MART-1 specific CD8+ T-cell immunity. J Immunother. 2006;29(5):545-557.

59. Atzpodien J, Reitz M. GM-CSF plus antigenic peptide vaccination in locally advanced melanoma patients. Cancer Biother Radiopharm. 2007;22(4):551-555. 
60. Spitler LE, Grossbard ML, Ernstoff MS, et al. Adjuvant therapy of stage III and IV malignant melanoma using granulocyte-macrophage colony-stimulating factor. J Clin Oncol. 2000;18(8):1614-1621.

61. Spitler LE, Weber RW, Allen RE, et al. Recombinant human granulocytemacrophage colony-stimulating factor (GM-CSF, sargramostim) administered for 3 years as adjuvant therapy of stages II(T4), III, and IV melanoma. J Immunother. 2009;32(6):632-637.

62. Dillman RO, DePriest C, de Leon C, et al. Patient-specific vaccines derived from autologous tumor cell lines as active specific immunotherapy: results of exploratory phase I/II trials in patients with metastatic melanoma. Cancer Biother Radiopharm. 2007;22(3):309-321.

63. Clive KS, Tyler JA, Clifton GT, et al. Use of GM-CSF as an adjuvant with cancer vaccines: beneficial or detrimental? Expert Rev Vaccines. 2010;9(5):519-525.

64. Weber J, Sondak VK, Scotland R, et al. Granulocyte-macrophagecolony-stimulating factor added to a multipeptide vaccine for resected stage II melanoma. Cancer. 2003;97(1):186-200.

65. Slingluff CL Jr, Petroni GR, Yamshchikov GV, et al. Clinical and immunologic results of a randomized phase II trial of vaccination using four melanoma peptides either administered in granulocytemacrophage colony-stimulating factor in adjuvant or pulsed on dendritic cells. J Clin Oncol. 2003;21(21):4016-4026.

66. Dillman RO, Wiemann M, Nayak SK, DeLeon C, Hood K, DePriest C. Interferon-gamma or granulocyte-macrophage colony-stimulating factor administered as adjuvants with a vaccine of irradiated autologous tumor cells from short-term cell line cultures: a randomized phase 2 trial of the cancer biotherapy research group. J Immunother. 2003;26(4): 367-373.

67. Faries MB, Hsueh EC, Ye X, Hoban M, Morton DL. Effect of granulocyte/macrophage colony-stimulating factor on vaccination with an allogeneic whole-cell melanoma vaccine. Clin Cancer Res. 2009;15(22):7029-7035.

68. Kirkwood JM, Lee S, Moschos SJ, et al. Immunogenicity and antitumor effects of vaccination with peptide vaccine+/-granulocyte-monocyte colony-stimulating factor and/or IFN-alpha2b in advanced metastatic melanoma: Eastern Cooperative Oncology Group Phase II Trial E1696. Clin Cancer Res. 2009;15(4):1443-1451.

69. Lawson DH, Lee SJ, Tarhini AA, et al. Presented at American Society of Clinical Oncology (ASCO) Annual Meeting, June 2010, Chicago, IL, USA. E4697: Phase III cooperative group study of yeast-derived granulocyte macrophage colony-stimulating factor (GM-CSF) versus placebo as adjuvant treatment of patients with completely resected stage III-IV melanoma. J Clin Oncol. 2010;28:15s (Suppl; abstr 8504).

70. Kantoff PW, Higano CS, Shore ND, et al. Sipuleucel-T immunotherapy for castration-resistant prostate cancer. N Engl J Med. 2010;363(5): $411-422$.

71. Hoon DS, Foshag LJ, Nizze AS, Bohman R, Morton DL. Suppressor cell activity in a randomized trial of patients receiving active specific immunotherapy with melanoma cell vaccine and low dosages of cyclophosphamide. Cancer Res. 1990;50(17):5353-5364.

72. Oratz R, Dugan M, Roses DF, et al. Lack of effect of cyclophosphamide on the immunogenicity of a melanoma antigen vaccine. Cancer Res. 1991;51(14):3643-3647.

73. Slingluff CL Jr, Petroni CR, Chianese-Bullock KA, et al. Randomized multicenter trial of the effects of melanoma-associated helper peptides and cyclophosphamide on the immunogenicity of a multipeptide melanoma vaccine. J Clin Oncol. 2011;29(21):2924-2932.

74. Attia P, Maker AV, Haworth LR, Rogers-Freezer L, Rosenberg SA. Inability of a fusion protein of IL-2 and diphtheria toxin (Denileukin Diftiox DAB 389IL-2, ONTAK) to eliminate regulatory T lymphocytes inpatients with melanoma. J Immunother. 2005;28(6):582-592.

75. Mahnke K, Schönfeld K, Fondel S, et al. Depletion of CD4+CD25+ human regulatory $\mathrm{T}$ cell in vivo: kinetics of Treg depletion and alterations in immune functions in vivo and in vitro. Int J Cancer. 2007;120(12):2723-2733.

76. Jacobs JF, Punt CJ, Lesterhuis WJ, et al. Dendritic cell vaccination in combination with anti-CD25 monoclonal antibody treatment: a phase I/II study in metastatic melanoma patients. Clin Cancer Res. 2010;16(20):5067-5078.
77. Mitchell DA, Cui X, Schmittling RJ, et al. Monoclonal antibody blockade of IL-2 receptor $\alpha$ during lymphopenia selectively depletes regulatory $\mathrm{T}$ cells in mice and humans. Blood. 2011;118(11): 3003-3012.

78. Topalian SL, Weiner GJ, Pardoll DM. Cancer immunotherapy comes of age. J Clin Oncol. 2011;29(36):4828-4838.

79. Pardoll DM. The blockade of immune checkpoints in cancer immunotherapy. Nat Rev Cancer. 2012;12(4):252-264.

80. Ileana E, Champiat S, Soria JC. Immune-checkpoints: the new anticancer immunotherapies. Bull Cancer. 2013;100(6):601-610.

81. Steinman RM. The dendritic cell system and its role in immunogenicity. Annu Rev Immunol. 1991;(9):271-296.

82. Hart DN. Dendritic cells: unique leukocyte populations which control the primary immune response. Blood. 1997;90(9):3245-3287.

83. Markiewicz MA, Kast WM. Progress in the development of immunotherapy of cancer using ex vivo-generated dendritic cells expressing multiple tumor antigen epitopes. Cancer Invest. 2004;22(3): 417-434.

84. Baggers J, Ratzinger G, Young JW. Dendritic cells as immunologic adjuvants for the treatment of cancer. J Clin Oncol. 2000;18(23): 3879-3882.

85. de Vries IJ, Lesterhuis WJ, Scharenborg NM, et al. Maturation of dendritic cells is a prerequisite for inducing immune responses in advanced melanoma patients. Clin Cancer Res. 2003;(9):54091-55100.

86. O'Neill DW, Adams S, Bhardwaj N. Manipulating dendritic cell biology for the active immunotherapy of cancer. Blood. 2004;104(8): 2235-2246.

87. Fonseca C, Dranoff G. Capitalizing on the immunogenicity of dying tumor cells. Clin Cancer Res. 2008;14(6):1603-1608.

88. Green DR, Ferguson, Zitvogel L, Kroemer G. Immunogenic and tolerogenic cell death. Nat Rev Immunol. 2009;9(5):353-363.

89. Shaif-Muthana I, McIntyre C, Sisley K, Rennie I, Murray A. Dead or alive: immunogenicity of human melanoma cells when presented by dendritic cells. Cancer Res. 2000;60(22):6441-6447.

90. de Vries IJ, Eggert AAO, Scharenborg NM, et al. Phenotypical and functional characterization of clinical grade dendritic cells. J Immunother. 2002;25(6):429-438.

91. O'Rourke MG, Johnson MK, Lanagan CM, et al. Dendritic cell immunotherapy for stage IV melanoma. Melanoma Res. 2007;17(5): 316-322.

92. Verdijk P, Aarntzen EH, Lesterhuis WJ, et al. Limited amounts of dendritic cells migrate in the T-cell area of lymph nodes but have high immune activating potential in melanoma patients. Clin Cancer Res. 2009;15(7):2531-2540.

93. Rouas R, Akl H, Fayyad-Kazan H, et al. Dendritic cells generated in clinical grade bags strongly differ in immune functionality when compared with classical DC generated in plates. $J$ Immunother. 2010;33(4):352-363.

94. Nestle FO, Alijagic S, Gilliet M, et al. Vaccination of melanoma patients with peptide-or tumor lysate-pulsed dendritic cells. Nat Med. 1998;4(3):328-332.

95. Hadzantonis M, O’Neill H. Review: dendritic cell immunotherapy for melanoma. Cancer Biother Radiopharm. 1999;14(1):11-22.

96. Zhang S, Wang Q, Miao B. Review: dendritic cell-based vaccine in the treatment of patients with advanced melanoma. Cancer Biother Radiopharm. 2007;22(4):501-507.

97. Nencioni A, Grünebach F, Schmidt SM, et al. The use of dendritic cells in cancer immunotherapy. Crit Rev Oncol Hematol. 2008;65(3): 191-199.

98. Eubel J, Enk AH. Dendritic cell vaccination as a treatment modality for melanoma. Expert Rev Anticancer Ther. 2009;9(11): $1631-1642$.

99. Engell-Noerregaard L, Hansen TH, Andersen MH, Thor Straten P, Svane IM. Review of clinical studies on dendritic cell-based vaccination of patients with malignant melanoma: assessment of correlation between clinical response and vaccine parameters. Cancer Immunol Immunother. 2009;58(1):1-14. 
100. Herlyn M, Koprowski H. Melanoma antigens: immunological and biological characterization and clinical significance. Ann Rev Immunol. 1988;6:283-308.

101. Seigler HF, Wallack MK, Vervaert CE, Bash JA, Roberson KM, Stuhlmiller GM. Melanoma patient antibody responses to melanoma tumor-associated antigens defined by murine monoclonal antibodies. J Biol Response Mod. 1989;8(1):37-52.

102. Ravindranath $\mathrm{MH}$, Morton DL. Immunogenicity of membranebound gangliosides in viable whole-cell vaccines. Cancer Invest. 1997; 15(5):491-499.

103. Livingston P. Ganglioside vaccines with emphasis on GM2. Semin Oncol. 1998;25(6):636-645.

104. Chapman PB, Morrissey DM, Panageas KS, et al. Induction of antibodies against GM2 ganglioside by immunizing melanoma patients using GM-2keyhole limpet hemocyanin + QS21 vaccine: a dose-response study. Clin Cancer Res. 2000;6(3):874-879.

105. Guthmann MD, Bitton RJ, Carnero AJL, et al. Active specific immunotherapy of melanoma with a GM3 ganglioside vaccine: a report on safety and immunogenicity. J Immunother. 2004;27(6): 442-451.

106. Foon KA, Sen G, Hutchins L, et al. Antibody responses in melanoma patients immunized with an anti-idiotype antibody mimicking disialoganglioside GD2. Clin Cancer Res. 1998;4(5):1117-1124.

107. Chapman PB, Morrisey D, Panageas KS, et al. Vaccination with a bivalent GM2 and GD2 ganglioside conjugate vaccine: a trial comparing doses of GD2-heyhole limpet hemocyanin. Clin Cancer Res. 2000;6(12):4658-4662.

108. Helling F, Shang A, Calves M, et al. GD3 vaccines for melanoma: superior immunogenicity of keyhole limpet hemocyanin conjugate vaccines. Cancer Res. 1994;54(1):197-203.

109. McCaffery M, Yao TJ, Williams L, Livingston PO, Houghton AN, Chapman P. Immunization of melanoma patients with BEC2 antiidiotypic monoclonal antibody that mimics GD3 ganglioside: enhanced immunogenicity when combined with adjuvant. Clin Cancer Res. 1996;2(4):679-686.

110. Applebaum J, Reynolds S, Knispel J, Oratz R, Shapiro R, Bystryn JC. Identification of melanoma antigens that are immunogenic in humans and expressed in vivo. J Natl Cancer Inst. 1998;90(2):146-149.

111. Kawakami Y, Dang N, Wang X, et al. Recognition of shared melanoma antigens in association with major HLA-A alleles by tumor infiltrating T lymphocytes from 123 patients with melanoma. J Immunother. 2000;23(1):17-27.

112. Castelli C, Rivoltini L, Andreola G, Carrabba M, Renkvist N, Parmiani G. T-cell recognition of melanoma-associated antigens. J Cell Physiol. 2000;182(3):323-331.

113. Parmiani G, Castelli C, Dalerba P, et al. Cancer immunotherapy with peptide-based vaccines: what have we achieved? Where are we going? J Natl Cancer Inst. 2002;94(11):805-818.

114. Brinkman JA, Fausch SC, Weber JS, Kast WM. Peptide-based vaccines for cancer immunotherapy. Expert Opin Biol Ther. 2004;4(2): 181-198.

115. Hodi FS. Well-defined melanoma antigens as progression markers for melanoma: insights into differential expression and host response based on stage. Clin Cancer Res. 2006;12(3 Pt 1):673-678.

116. Barrow C, Browning J, MacGregor D, et al. Tumor antigen expression in melanoma varies according to antigen and stage: 1a. Clin Cancer Res. 2006;12(3 Pt 1):764-771.

117. Weide B, Zelba H, Derhovanessian E, et al. Functional T cells targeting NY-ESO-1 or Melan-A are predictive for survival of patients with distant melanoma metastasis. J Clin Oncol. 2012;30(15): 1835-1841.

118. Mittelman A, Chen GZ, Wong GY, Liu C, Hirai S, Ferrone S. Human high molecular weight associated antigen mimicry by mouse antiidiotypic monoclonal antibody MK2-23: modulation of the immunogenicity in patients with malignant melanoma. Clin Cancer Res. 1995;1(7):705-713.

119. Foon KA, Lutzky J, Baral RN, et al. Clinical and immune responses in advanced melanoma patients immunized with an anti-idiotype antibody mimicking disialoganglioside GD2. J Clin Oncol. 2000;18(2): 376-384.
120. Osorio M, Gracia E, Reigosa E, et al. Effect of vaccination with $\mathrm{N}$-glycolyl GM3/VSSP vaccine by subcutaneous injection in patients with advanced cutaneous melanoma. Cancer Manag Res. 2012;(4): 341-345

121. Chapman PB, Wu D, Ragupathi G, et al. Sequential immunization of melanoma patients with GD3 ganglioside vaccine and anti-idiotypic monoclonal antibody that mimics GD3 ganglioside. Clin Cancer Res. 2004;10(14):4717-4723.

122. Livingston PO, Wong GY, Adluri S, et al. Improved survival in stage III melanoma patients with GM2 antibodies: a randomized trial of adjuvant vaccination with GM2 ganglioside. J Clin Oncol. 1994;12(5):1036-1044.

123. Kirkwood JM, Ibrahim JG, Sosman JA, et al. High-dose interferon alfa-2b significantly prolongs relapse-free and overall survival compared with the GM2-KLH/QS-21 vaccine in patients with resected stage IIB-III melanoma: results of intergroup trial E1694/S9512/ C509801. J Clin Oncol. 2001;19(9):2370-2380.

124. Estin CD, Stevenson US, Plowman GC, et al. Recombinant vaccinia virus vaccine against the human melanoma antigen p97 for use in immunotherapy. Proc Natl Acad Sci U S A. 1988;85(4):1052-1056.

125. Cormier JN, Salgaller ML, Prevette T, et al. Enhancement of cellular immunity in melanoma patients immunized with MART-1/MelanA. Cancer J Sci Am. 1997;3(1):37-44.

126. Peterson AC, Harlin H, Gajewski TF. Immunization with Melan-A peptide pulsed peripheral blood mononuclear cells plus recombinant human interleukin-12 induces clinical activity and T-cell responses in advanced melanoma. J Clin Oncol. 2003;21(12):2342-2348.

127. Smith JW 2nd, Walker BA, Fox BA, et al. Adjuvant immunization of HLA-A2-positive melanoma patients with a modified gp100 peptide induces peptide-specific CD8+ T-cell responses. J Clin Oncol. 2003;21(8):1562-1573.

128. Rosenberg SA, Sherry RM, Morton KE, et al. Tumor progression can occur despite the induction of very high levels of self/tumor antigen specific CD8+ T cells in patients with melanoma. J Immunol. 2005;175(9):6169-6176.

129. Sosman JA, Carrillo C, Urba WJ, et al. Three phase II cytokine working group trials of gp100 (210M) peptide plus high-dose interleukin-2 patients with HLA-A2-positive advanced melanoma. J Clin Oncol. 2008;26(14):2292-2298

130. Lesterhuis WJ, Schreibelt G, Scharenborg NM, et al. Wild-type and modified gp100 peptide-pulsed dendritic cell vaccination of advanced melanoma patients can lead to long-term clinical responses independent of the peptide used. Cancer Immunol Immunother. 2011;60(2): 249-260.

131. Marchand M, Punt CJ, Aamdal S, et al. Immunisation of metastatic cancer patients with MAGE-3 protein combined with adjuvant SBAS-2: a clinical report. Eur J Cancer. 2003;39(1):70-77.

132. Kruit WH, van Ojik HH, Brichard VG, et al. Phase $1 / 2$ study of subcutaneous and intradermal immunization with a recombinant MAGE-3 protein in patients with detectable metastatic melanoma. Int J Cancer. 2005;117(4):596-604.

133. van Baren N, Bonnet MC, Dréno B, et al. Tumoral and immunologic response after vaccination of melanoma patients with an ALVAC virus encoding MAGE regions recognized by T cells. J Clin Oncol. 2005;23(35):9008-9021.

134. Hersey P, Menzies SW, Halliday GM, et al. Phase I/II study of treatment with dendritic cell vaccines in patients with disseminated melanoma. Cancer Immunol Immunother. 2004;53(2):125-134.

135. Tagawa ST, Cheung E, Banta W, Gee C, Weber JS. Survival analysis after resection of metastatic disease followed by peptide vaccines in patients with stage IV melanoma. Cancer. 2006;106(6): 1353-1357.

136. Tarhini AA, Leng S, Moschos SJ, et al. Safety and immunogenicity of vaccination with MART-1 (26-35, 27 L), gp100 (209-217, 210M), and tyrosinase $(368-376,370 \mathrm{D})$ in adjuvant with PF-3512676 and GM-CSF in metastatic melanoma. J Immunother. 2012;35(4): 359-366. 
137. Banchereau J, Ueno H, Dhodapkar M, et al. Immune and clinical outcomes in patients with stage IV melanoma vaccinated with peptidepulsed dendritic cells derived from CD34+ progenitors and activated with type 1 interferon. J Immunother. 2005;28(5):505-516.

138. Hersey P, Halliday GM, Farrelly ML, et al. Phase I/II study of treatment with matured dendritic cells with or without low dose IL-2 in patients with disseminated melanoma. Cancer Immunol Immunother. 2008;57(7):1039-1051.

139. Slingluff CL Jr, Petroni GR, Olson W, et al. Helper T-cell responses and clinical activity of a melanoma vaccine with multiple peptides from MAGE and melanocytic differentiation antigens. J Clin Oncol. 2008;26(30):4973-4980.

140. Slingluff CL Jr, Petroni GR, Yamshchikov GV, et al. Immunologic and clinical outcomes of vaccination with a multiepitope melanoma peptide vaccine plus low-dose interleukin-2 administered either concurrently or on a delayed schedule. J Clin Oncol. 2004;22(22): 4474-4485.

141. Schadendorf D, Ugurel S, Schuler-Thurner B, et al; DC study group of the DeCOG. Dacarbazine (DTIC) versus vaccination with autologous peptide-pulsed dendritic cells (DC) in first-line treatment of patients with metastatic melanoma: a randomized phase III trial of the DC study group of the DeCOG. Ann Oncol. 2006;17(4): 563-570.

142. Slingluff CL Jr, Petroni BR, Chianese-Bullock KA, et al. Immunologic and clinical outcomes of a randomized phase II trial of two multipeptide vaccines for melanoma in the adjuvant setting. Clin Cancer Res. 2007;13(21):6386-6395.

143. Kruit WH, Suciu S, Dreno B, et al. Selection of immunostimulant AS15 for active immunization with MAGE-A3 protein: results of a randomized Phase II study of the European Organisation for Research and Treatment of Cancer Melanoma Group in metastatic melanoma. J Clin Oncol. 2013;(19):2413-2420.

144. Schwartzentruber DJ, Lawson DH, Richards JM, et al. Gp100 peptide vaccine and interleukin-2 in patients with advanced melanoma. $N$ Engl J Med. 2011;364(22):2119-2127.

145. Odunsi K, Matsuzaki J, Karbach J, et al. Efficacy of vaccination with recombinant vaccinia and fowlpox vectors expressing NY-ESO-1 antigen in ovarian cancer and melanoma patients. Proc Natl Acad Sci US A. 2012;109(15):5797-5802.

146. McGee JM, Lytle GH, Malnar KF, Price JA, Humphrey LJ. Melanoma tumor vaccine: five-year follow-up. J Surg Oncol. 1991;47(4): 233-238.

147. McGee JM, Patten MR, Malnar KF, Price JA 3rd, Mayes JS, Watson GH. Comparison of melanoma antigens in whole tumor vaccine to those from IIB-MEL-J Cells. Cancer Biother Radiopharm. 1999;14(3):203-208.

148. Hollinshead A, Arlen M, Yonemoto R, et al. Pilot studies using melanoma tumor-associated antigens (TAA) in specific-active immunochemotherapy of malignant melanoma. Cancer. 1982;49(7): 1387-1404.

149. Bystryn JC, Zeleniuch-Jacquotte A, Oratz R, Shapiro RL, Harris MN, Roses DF. Double-blind trial of a polyvalent, shed-antigen, melanoma vaccine. Clin Cancer Res. 2001;7(7):1882-1887.

150. Wallack MK, Sivanandham M, Balch CM, et al. A phase III randomized, double-blind multiinstitutional trial of vaccinia melanoma oncolysate-active specific immunotherapy for patients with stage II melanoma. Cancer. 1995;75(1):34-42.

151. Wallack MK, Sivanandham M, Balch CM, et al. Surgical adjuvant active specific immunotherapy for patients with stage III melanoma: the final analysis of data from a phase III, randomized, double-blind, multicenter vaccinia melanoma oncolysate trial. J Am Coll Surg. 1998;187(1):69-77.

152. Hersey P, Coates AS, McCarthy WH, et al. Adjuvant immunotherapy of patients with high-risk melanoma using vaccinia viral lysates of melanoma: results of a randomized trial. J Clin Oncol. 2002;20(20): 4181-4190.

153. Sondak VK, Liu PY, Tuthill RJ, et al. Adjuvant immunotherapy of resected, intermediate-thickness, node-negative melanoma with an allogeneic tumor vaccine: overall results of a randomized trial of the Southwest Oncology Group. J Clin Oncol. 2002;20(8): 2058-2066.
154. Mitchell MS, Abrams J, Thompson JA, et al. Randomized trial of an allogeneic melanoma lysate vaccine with low-dose interferon Alfa- $2 b$ compared with high-dose interferon Alfa-2b for resected stage III cutaneous melanoma. J Clin Oncol. 2007;25(15):2078-2085.

155. Morton DL, Mozzillo N, Thompson JF, et al. Presented at American Society of Clinical Oncology (ASCO) Annual Meeting, June 2007, Chicago, IL, USA. An international, randomized, phase III trial of bacillus Calmette-Guerin (BCG) plus allogeneic melanoma vaccine (MCV) or placebo after complete resection of melanoma metastatic to regional or distant sites. J Clin Oncol. 2007;25:474s (abstr 8508).

156. Morton DL, Foshag LJ, Hoon DS, et al. Prolongation of survival in metastatic melanoma after active specific immunotherapy with a new polyvalent melanoma vaccine. Ann Surg. 1992;216(4):463-482.

157. Hsueh EC, Essner R, Foshag LJ, et al. Prolonged survival after complete resection of disseminated melanoma and active immunotherapy with a therapeutic cancer vaccine. J Clin Oncol. 2002;20(23):4549-4554.

158. Bystryn JC, Oratx R, Harris MN, Roses DF, Golomb FM, Speyer JL. Immunogenicity of a polyvalent melanoma antigen vaccine in humans. Cancer. 1988;61(6):1065-1070.

159. Salcedo M, Bercovici N, Taylor R, et al. Vaccination of melanoma patients using dendritic cells loaded with an allogeneic tumor cell lysate. Cancer Immunol Immunother. 2006;55(7):819-829.

160. Lopez MN, Pereda C, Segal G, et al. Prolonged survival of dendritic cellvaccinated melanoma patients correlates with tumor-specific delayed type IV hypersensitivity response and reduction of tumor growth factor beta-expressing cells. J Clin Oncol. 2009;27(6):945-952.

161. Ribas A, Camacho LH, Lee SM, et al. Multicenter phase II study of matured dendritic cells pulsed with melanoma cell line lysates in patients with advanced melanoma. J Transl Med. 2010;8:89.

162. Laucius JF, Bodurtha AJ, Mastrangelo MJ, Bellet RE. A phase II sutdy of autologous irradiated tumor cells plus BCG in patients with metastatic malignant melanoma. Cancer. 1977;40(5):2091-2093.

163. Berd D, Maguire HC Jr, McCue P, Mastrangelo MJ. Treatment of metastatic melanoma with an autologous tumor-cell vaccine: clinical and immunologic results in 64 patients. J Clin Oncol. 1990;8(11): 1858-1867.

164. Berd D, Maguire HC Jr, Schuchter LM, et al. Autologous haptenmodified melanoma vaccine as postsurgical adjuvant treatment after resection of nodal metastases. J Clin Oncol. 1997;15(6):2359-2370.

165. Berd D, Sato T, Maguire HC, Kairys J, Mastrangelo MJ. Immunopharmacologic analysis of an autologous hapten-modified human melanoma vaccine. J Clin Oncol. 2004;22(3):403-415.

166. Eton O, Kharkevitch DD, Gianan MA, et al. Active immunotherapy with ultraviolet B-irradiated autologous whole melanoma cells plus DETOX in patients with metastatic melanoma. Clin Cancer Res. 1998;4(3):619-627.

167. O'Rourke MG, Johnson M, Lanagan C, et al. Durable complete clinical responses in a phase I/II trial using an autologous melanoma cell/ dendritic cell vaccine. Cancer Immunol Immunother. 2003;52(6): 387-395.

168. Ridolfi L, Petrini M, Fiammenghi L, et al. Dendritic cell-based vaccine in advanced melanoma: update of clinical outcome. Melanoma Res. 2011;21(6):524-529.

169. Redman BG, Chang AE, Whitfield J, et al. Phase Ib trial assessing autologous, tumor-pulsed dendritic cells as a vaccine administered with or without IL-2 in patients with metastatic melanoma. J Immunother. 2008;31(6):591-598.

170. Krause SW, Neumann C, Soruri A, Mayer S, Peters JH, Andressen R. The treatment of patients with disseminated malignant melanoma by vaccination with autologous cell hybrids of tumor cells and dendritic cells. J Immunother. 2002;25(5):421-428.

171. Haenssle H, Krause SW, Emmert S, et al. Hybrid cell vaccination in metastatic melanoma: clinical and immunologic results of a phase I/II study. J Immunother. 2004;27(2):147-155.

172. Wei Y, Sticca RP, Holmes LM, et al. Dendritoma vaccination combined with low dose interleukin-2 in metastatic melanoma patients induced immunological and clinical responses. Int J Oncol. 2006;28(3):585-593. 
173. Berd D. M-Vax: an autologous, hapten-modified vaccine for human cancer. Expert Rev Vaccines. 2004;3(5):521-527.

174. Berd D. A tale of two pities: autologous melanoma vaccines on the brink. Hum Vaccin Immunother 2012;8(8):1146-1151.

175. Holmes LM, Li J, Sticca RP, Wagner TE, Wei Y. A rapid, novel strategy to induce tumor cell-specific cytotoxic $\mathrm{T}$ lymphocyte responses using instant dendritomas. J Immunother. 2001;24(2):122-129.

176. Soruri A, Fayyazi, Neumann C, et al. Ex vivo generation of human anti-melanoma autologous cytolytic $\mathrm{T}$ cells by dendritic cell melanoma cell hybridomas. Cancer Immunol Immunother. 2001; 50(6):307-3014.

177. Srivastava PK, Jaikaria NS. Methods of purification of heat shock protein-peptide complexes for use as vaccines against cancers and infectious diseases. Methods Mol Biol. 2001;(156):175-186.

178. Belli F, Testori A, Rivoltini L, et al. Vaccination of metastatic melanoma patients with autologous tumor-derived heat shock protein gp96-peptide complexes: clinical and immunologic findings. $J$ Clin Oncol. 2002;20(20):4169-4180.

179. Testori A, Richards J, Whitman E, et al; C-100-21 Study Group. Phase III comparison of vitespen, an autologous tumor-derived heat shock protein gp96 peptide complex vaccine, with physician's choice of treatment for stage IV melanoma: the C-100-21 Study Group. $J$ Clin Oncol. 2008;26(6):955-962.

180. Dillman RO, Nayak SK, Beutel L. Establishing in vitro cultures of autologous tumor cells for use in active specific immunotherapy. J Immunother. 1993;14(1):65-69.

181. Dillman RO, Cornforth AN, Nistor G. Cancer stem cell antigenbased vaccines: the preferred strategy for active specific immunotherapy of metastatic melanoma? Expert Opin Biol Ther. 2013 13(5):643-656.

182. Schatton T, Frank MH. Cancer stem cells and human malignant melanoma. Pigment Cell Melanoma Res. 2008;21(1):39-55.

183. Schatton T, Frank MH. Antitumor immunity and cancer stem cells. Ann N Y Acad Sci. 2009;1176:154-169.

184. Boiko AD, Razorenova OV, van de Rijn M, et al. Human melanomainitiating cells express neural crest nerve growth factor receptor CD271. Nature. 2010;466(7302):133-137.

185. Civennia G, Kobert N, Mihic-Probst D, et al. Human CD271positive melanoma stems cell associated with metastasis establish tumor heterogeneity and long-term growth. Cancer Res. 2011;71(8): 3098-3109.

186. Ramgolam K, Lauriol J, Lalou C, et al. Melanoma spheroids grown under neural crest cell conditions are highly plastic migratory/invasive tumor cells endowed with immunomodulator function. PLoS One 2011;6(4):e18784.

187. Lang D, Mascarenhas JB, Shea CR. Melanocytes, melancyte stem cells, and melanoma stem cells. Clin Dermatol. 2013;31(2):166-178.

188. Boiko AD. Isolation of melanoma tumor-initiating cells from surgical tissues. Methods Mol Biol. 2013;961:253-259.

189. Schmidt P, Kopecky C, Hombach A, Zigrino P, Mauch C, Abken H. Eradication of melanomas by targeted elimination of a minor subset of tumor cells. Proc Natl Acad Sci U S A. 2011;8:108(6):2474-2479.

190. Dillman RO, Selvan SR, Schlitz PM. Patient-specific dendritic cell vaccines for metastatic melanoma. $N$ Engl J Med. 2006;355(11): 1179-1181.

191. Selvan SR, Carbonell DJ, Fowler AW, Beatty AR, Ravindranath MH, Dillman RO. Establishment of stable cell lines for personalized melanoma cell vaccine. Melanoma Res. 2010;20(4):280-292.

192. Cornforth AN, Fowler AW, Carbonell DJ, Fan E, Dillman RO. Characterization of interferon- $\gamma$-treated melanoma tumor cells for use in dendritic cell-based immunotherapy. Cancer Biother Radiopharm. 2011;26(3):345-351.

193. Dillman RO, Selvan SR, Schiltz PM, et al. Phase II trial of dendritic cells loaded with antigens from self-renewing, proliferating autologous tumor cells as patient-specific anti-tumor vaccines in patients with metastatic melanoma: final report. Cancer Biother Radiopharm. 2009;24(3):311-319.
194. Dillman RO, Cornforth AN, Depriest C, et al. Tumor stem cell antigens as consolidative active specific immunotherapy: a randomized phase II trial of dendritic cells versus tumor cells in patients with metastatic melanoma. J Immunother. 2012;35(8):641-649.

195. Dillman RO, Nanci AA, Williams ST, et al. Durable complete response of refractory, progressing metastatic melanoma after treatment with a patient-specific vaccine. Cancer Biother Radiopharm. 2010;25(5): $553-557$.

196. Cornforth AN, Fowler AW, Carbonell DJ, Dillman RO. Resistance to the proapoptotic effects of interferon-gamma on melanoma cells used in patient-specific dendritic cell immunotherapy is associated with improved overall survival. Cancer Immunol Immunother. 2011;60(1): 123-131.

197. Dillman RO, Fogel GB, Cornforth AN, Selvan SR, Schiltz PM, DePriest $C$. Features associated with survival in metastatic melanoma patients treated with patient-specific vaccines consisting of proliferating autologous tumor cells and autologous dendritic cells. Cancer Biother Radiopharm. 2011;26(4):407-415.

198. Abdel-Wahab Z, Weltz C, Hester D, et al. A phase I trial of immunotherapy with interferon- $\gamma$ gene-modified autologous melanoma cells: monitoring the humoral immune response. Cancer. 1997;80(3): 401-412.

199. Kusumoto M, Umeda S, Ikubo A, et al. Phase I clinical trial of irradiated autologous melanoma cells adenovirally transduced with human GM-CSF gene. Cancer Immunol Immunother. 2001;50(7): 373-381

200. Soiffer R, Hodi S, Haluska F, et al. Vaccination with irradiated, autologous melanoma cells engineered to secrete granulocytemacrophage colony-stimulating factor by adenoviral-mediated gene transfer augments antitumor immunity in patients with metastatic melanoma. J Clin Oncol. 2003;21(17):3343-3350.

201. Triozzi PL, Tuthill RJ, Borden E. Re-inventing intratumoral immunotherapy for melanoma. Immunotherapy. 2011;3(5):653-671.

202. Tan JK, Ho VC. Pooled analysis of the efficacy of bacilli CalmetteGuerin (BCG) immunotherapy in malignant melanoma. J Dermatol Surg Oncol. 1993;19(11):985-990.

203. Von Wussow P, Block B, Hartmann F, Deicher H. Intralesional interferon-alpha therapy in advanced malignant melanoma. Cancer 1988;61(6):1071-1074.

204. Nemunaitis J, Fong T, Burrows F, et al. Phase I trial of interferon gamma retroviral vector administered intratumorally with multiple courses in patients with metastatic melanoma. Hum Gene Ther. 1999;10(8):1289-1298.

205. Weide B, Derhovanessian E, Pflugfelder A, et al. High response rate after intratumoral treatment with interleukin-2: results from a phase 2 study in 51 patients with metastasized melanoma. Cancer. 2010;116(17):4139-4146.

206. Si Z, Hersey P, Coates AS. Clinical responses and lymphoid infiltrates in metastatic melanoma following treatment with intralesional GM-CSF. Melanoma Res. 1996;6(3):247-255.

207. Stopeck AT, Hersh EM, Akporiaye ET, et al. Phase I study of direct gene transfer of an allogeneic histocompatibility antigen, HLA-B7, in patients with metastatic melanoma. J Clin Oncol. 1997;15(1): 341-349.

208. Stopeck AT, Jones A, Hersh EM, et al. Phase II study of direct intralesional gene transfer of allovectin-7, an HLA-B7/32-microglobulin DNA-liposome complex, in patients with metastatic melanoma. Clin Cancer Res. 2001;7(8):2285-2291.

209. Bedikian AY, Richards J, Kharkevitch D, Atkins MB, Whitman E, Gonzalez R. A phase 2 study of high-dose allovectin-7 in patients with advanced metastatic melanoma. Melanoma Res. 2010;20(3): 218-226.

210. Senzer NN, Kaufman HL, Amatruda T, et al. Phase II clinical trial of a granulocyte-macrophage colony-stimulating factorencoding, second-generation oncyloytic herpesvirus in patients with unresectable metastatic melanoma. J Clin Oncol. 2009;27(34): $5763-5771$. 
211. Kaufman HL, Kim DW, DeRaffele G, Mitcham J, Coffin RS, Kim-Schulze S. Local and distant immunity induced by intralesional vaccination with an oncolytic herpes virus encoding GM-CSF inpatients with stage IIIC and IV melanoma. Ann Surg Oncol. 2010;17(3):718-730.

212. Kaufman HL, Lutzky J, Clark J, et al. OPTiM: a randomized phase III trial of talimogene laherparepvec (T-VEC) versus subcutaneous (SC) granulocyte-macrophage colony-stimulating factor (GM-CSF) for the treatment (tx) of unresected stage IIIB/C and IV melanoma. J Clin Oncol. 2013;31 (Suppl; abstr LBA9008).
213. Edge SB, Byrd DR, Compton CC, Fritz AG, Green FL, Trotti A, editors. Melanoma of the skin. In: Cancer Staging Manual. 7th ed. American Joint Committee on Cancer (AJCC); Springer, NY, USA 2010:387-415.

\section{Publish your work in this journal}

Vaccine: Development and Therapy is an international, peer-reviewed, open access journal that spans the spectrum of vaccine design and development through to clinical applications. The journal is characterized by the rapid reporting of application notes, reviews, original research and clinical studies in all therapeutic areas. Clinical outcomes, patient safety, and programs for the development and effective, safe, and sustained use of vaccines will be a feature of the journal. The manuscript management system is completely online and includes a very quick and fair peer-review system. Visit http://www.dovepress.com/testimonials.php to read real quotes from published authors. 